\title{
The Metamorphosis of Contract into Expand
}

\author{
David Nimmer \\ Elliot Brown \\ Gary N. Frischling $\dagger$
}

TABLE of CONTENTS

The Death of Copyright: A Short, Cautionary Tale ..............................20

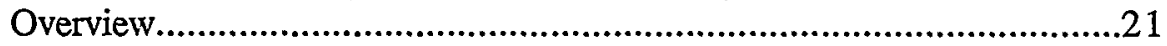

I. The Inevitable Coexistence of Copyright and Contract...................24

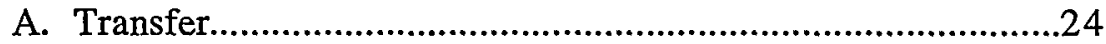

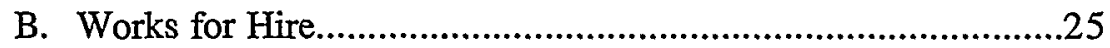

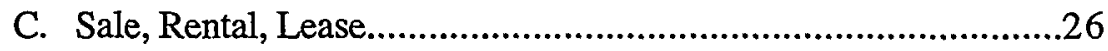

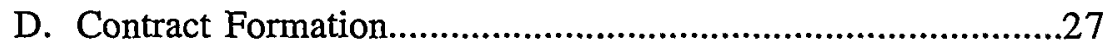

E. Limits of Contract Rights .........................................................27

II. Contract Need Play No Role in Protecting

Copyright Rights

A. Enforceability of Unilateral License Terms ............................30

B. The Conflation of Licensing With Distribution.........................34

III. The Limits on Contract via the Preemptive

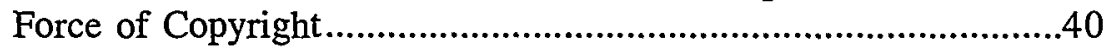

A. General Preemption Notions.................................................40

B. A Case Study in the Contract/Copyright Clash:

ProCD v. Zeidenberg.

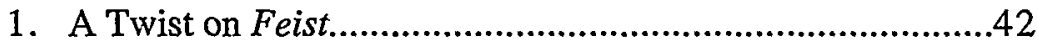

2. Issues State and Federal ..................................................42

3. A Step Back into History ..................................................44

C. Preemption Analysis of ProCD ...............................................45

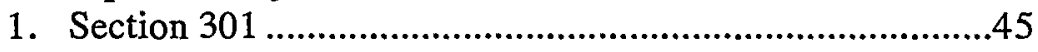

2. Giving Supremacy to the Supremes .................................50

D. Framework of Preemption Principles:

To the Limits of Monopoly ...................................................63

1. Permissible Limitations .....................................................65

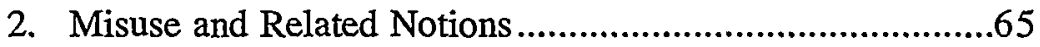

Copyright $\odot 1999$ David Nimmer, Elliot Brown, and Gary N. Frischling.

$\dagger$ The authors practice copyright law at Irell \& Manella LLP in Los Angeles. 
3. Within the Subject Matter of Copyright Even as to Unprotected Works .66

4. Difficulty of Drawing the Lines of Fair Use ...................66

IV. Some Lessons for the U.C.C. ................................................68

A. The Neutrality Myth........................................................69

B. How the U.C.C. Might Help Maintain the "Delicate Balance"...........................................................72

Conclusion ........................................................................76 


\title{
The Metamorphosis of Contract into Expand
}

\author{
David Nimmer \\ Elliot Brown \\ Gary N. Frischling
}

Article $2 B$ of the Uniform Commercial Code (U.C.C.) provides model rules to govern transactions in the digital domain, such as the licensing of software and electronic contracting. By addressing fundamental contract issues in the burgeoning world of digital commerce, it provides a salutary update to extant provisions of the U.C.C. dealing with traditional goods sold in traditional modes of commerce. However, to the extent that Article $2 B$ aspires to protect copyright owners from improper uses of copyrighted works, it solves a non-problem. Copyright owners already enjoy robust and adequate protections under the Copyright Act. Far more troubling than solving this non-problem, however, is the possibility that Article $2 B$ will be used to upset copyright law's "delicate balance" between the rights of copyright owners and copyright users. This balance is disrupted when state law is permitted to enlarge the rights that copyright owners enjoy.

Attempts to alter the "delicate balance" through contract should fail under the doctrine of preemption. Article $2 B$ assumes a pose of neutrality on the extent to which copyright law preempts contractual encroachment, yet it facilitates emerging practices designed to alter the balance and place the burden of defending the proper bounds of copyright on copyright users. In this Article, the authors argue that if Article $2 B$ is to be enacted, it must proscribe contracting practices that seek to extend copyright protection beyond its current scope. 


\section{The Death of Copyright: ${ }^{1}$ A Short, Cautionary Tale}

The year is 2010. With the closure of the last B\&N-WaldenBorders-Broadway superstore in Upton, California, no more off-line retail content stores remain in the United States (apart from the Scholar's Palazzo in Disneyland). Theaters, music venues, and movie houses have all but disappeared in the wake of in-home-not to mention implantable-content delivery. Funding for public libraries and the arts has been diverted into providing each person in America with access to the all-purpose device for accessing anything-Microsquish Audiovisual Utilization System (MAUS).

Now, anyone who wishes to read poetry, browse great works of art, enjoy a novel, watch an epic feature film (or humble television show), or experience any other work of authorship can, as a practical matter, do so only through the instrumentality of the MAUS. To access any work through the MAUS, the user must first click "OK" (or, in the case of implantable access, blink a cortical acknowledgment) on the ubiquitous authorization screen. That screen lets the user acknowledge that she agrees to be obligated to abide by all terms and provisions of $<$ http://www.contracts.com/ usurious_perpetual_adhesive_overreaching / $2001 \$ \$ \$ £ ¥$.html>. This file (colloquially known as the "Gates from Hell Agreement") contains a hundred pages of boilerplate initially setting forth the text of Title 17, United States Code, in haec verba, but thereafter subject to innumerable accretions, modifications, and revisions designed to inagnify the rights of proprietors.

Some companies had initially expressed reluctance at committing their works to protection under the foregoing regime; they were concerned that end users would find a way to circumvent the click-wrap conteinplated above. However, with a nod to Ovid, the MYRRHA Encryption/Subversion Systeins furnished the answer. Thanks to MYRRHA, it has been conclusively proven that no one anywhere can ever obtain access to any protected works in any form whatsoever without personally clicking on the omnipresent authorization screen. In addition, proprietors take heart from the fact that to buy any current equipment capable of accessing content, users must sit down for a half-hour tutorial at the appliance store and personally and meticulously agree to the Gates from Hell Agreement. The user's assent is, in each instance, routinely recorded on DCDVDB crystal, capturing for

1. With apologies to Professor Grant Gilmore, author of The Death of Contract (1974). Rumors of contract's death proved, of course, to be greatly exaggerated, as will be evident from the analysis herein. Moreover, the true speeter confronted today is not so much the death of copyright per se, but rather copyright as we know it-a law striking a balance between the rights of copyright owners and the rights of the public. Cf. David Nimmer, The End of Copyright, 48 VAND. L. Rev. 1385 (1995) (arguing that new trade discipline has eviscerated traditional notions of autonomy in the copyright arena). 
posterity not only the user's facial expression and utterances, but also her brain state manifestimg willing and voluntary assent.

\section{OVERVIEW}

In a commercial world burgeoning with transactions involving software and other electronically-delivered copyrighted works, an oftexpressed concern arises that traditional rules of commercial contract law-which evolved to address trade in goods - will prove ill-suited to address the peculiar needs of trade in digital products. The Uniform Commercial Code, after all, arose to address the paradigm of a sale of goods, a context that typically involves, at least in part, a negotiated contract between buyer and seller and where the value lies in the physical object exchanged. The typical software transaction, by contrast, does not involve a direct sale between the software proprietor and the end user; rather, it involves a non-negotiated license (otherwise known as a "shrinkwrap" contract) governing uses of the intangible asset (for example, software) einbodied in a tangible thing that is sold (for exainple, the diskette or CD-ROM) - or even absent the nominal sale of a tangible thing (for exainple, delivery directly over the Internet). It is natural to suspect that the law for widgets may be inadequate for digits. ${ }^{2}$

It is here that Article $2 \mathrm{~B}$ of the Uniform Commercial Code comes to the rescue. The proposed unodel law addresses nuany of the questions on which traditional commercial contract law is silent, for instance, whether a digital signature constitutes adequate consent to a contract, ${ }^{3}$ what warranties attach to digital products, ${ }^{4}$ what choice-of-law rules apply in transactions over the Internet, ${ }^{5}$ what rules govern the transferability of a license, and how notions of mitigation, consequential dan1ages, releases, inspection, etc., operate in the context of digital products. ${ }^{6}$ In sum, it provides some nieasure of certainty to electronic contracting.

Because Article $2 \mathrm{~B}$ accommodates contracts over copyrightable subject inatter, it is relevant to both the federal and state law planes of

2. "A body of law tailored to transactions whose purpose is to pass title to tangible property can not be simply applied to transactions whose purpose was to convey rights in intangible property and information." U.C.C. art. 2B, Preface at 4 (Draft, Mar. 1998). [All versions of Article 2B are available on the Internet. See National Conference of Commissioners on Uniform State Laws, Drafts of Uniform and Model Acts Official Site (last nodified Sept. 2, 1998) <http://www.law.upenn.edu/ library/ulc/ulc.htm>. The Official Site offers the Article 2B drafts in several file formats, among which the pagination is inconsistent. In this Article and throughout this issue of the California Law Review, page references are to the pages as they are numbered in the Acrobat PDF file format. Only the prefaces to the drafts are cited by page number; all other inaterial is cited by section number. The draft of August 1, 1998, has no page numbers in its on-line versions, and therefore the preface of that draft is cited without page references. $E d$.]

3. See U.C.C. \$ 2B-113 (Draft, Mar. 1998).

4. See id. $\S \S 2 \mathrm{~B}-401-409$.

5. See id. § 2B-107.

6. See id. $\S \S 2 \mathrm{~B}-502,608,701-716$. 
legal discourse. As discussed below, the symbiosis between federal copyright protection and state contract law is ancient, inevitable, and fully consonant with the purposes of copyright. In developing the law of contracts for the "digital era," Article 2B therefore represents a salutary update to the U.C.C. that can benefit both buyers and sellers of digital goods by providing clear rights and guidance in matters beyond the experience and imagination of the drafters of the current U.C.C.? Article $2 \mathrm{~B}$ thus carries on the role that state contract law has traditionally occupied in shaping commerce in copyrighted works.

But harmony is not the end of the symphony. ${ }^{8}$ When examined in light of its potential impact on copyright law's "delicate balance," Article $2 B$ presents the specter of becoming an unwelcome meddler. On the one hand, Article $2 \mathrm{~B}$ might erroneously be imagined to solve a fundamental problem that does not need solving-protecting the rights of copyright proprietors insofar as third parties exploit the intangible expression underlying their works. On the other hand, Article $2 \mathrm{~B}$ ignores and potentially weakens the rights of copyright users. These two phenomena are interrelated.

As discussed below, ${ }^{10}$ Article 2B solves a non-problem to the extent that it aspires to protect the exclusive rights of authors granted under the Copyright Act from improper uses of digital products by end users. The rights of copyright proprietors are already fully protected by the Copyright Act without the need for bilateral contracts, and thus a fortiori without the need for any provisions under the U.C.C. validating mass market contracts.

Solving a non-problem for copyright proprietors may do no harm, but Article 2B's framework threatens to create new problems for copyright users. As further discussed below, ${ }^{11}$ the copyright laws are designed

7. Although fashioned for the needs of digital commerce, Article $2 \mathrm{~B}$ theoretically allows proprietors of traditional copyrighted works (such as books) to "opt-in" to its framework as an alternative to the classic structure of Article 2. See U.C.C. $\$ 2 B-103$ (c) (Draft, Mar. 1998). As will be diseussed below, applying Article $2 B$ to old-fashioned copyrighted works creates a potential for mischief.

8. Part of the dissonance stems from Microsoft v. Harmony, 846 F. Supp. 208 (E.D.N.Y. 1994), discussed infra in Section II.B.

9. The metaphor of a delicate balance or cquilibrium is widespread. As one court has articulated it: "[T]he copyright law seeks to establish a delicate equilibrium. On the one hand, it affords protection to authors as an incentive to create, and, on the other, it must appropriately limit the extent of that protection so as to avoid the effects of monopolistic stagnation. In applying the federal act to new types of cases, courts must always keep this symmetry in mind." Computer Assocs. Int'l, Inc. v. Altai, Inc., 982 F.2d 693, 696 (2d Cir. 1992). We will refer to this "delicate balanee" often, tracing its genealogy through Supreme Court cases and to Chief Judge Crabb's opinion in ProCD, Inc. v. Zeidenberg, 908 F. Supp. 640 (W.D. Wis.), rev'd, 86 F.3d 1447 (7th Cir. 1996), treated at length below.

10. See infra Part II.

11. See infra Part IV. 
to achieve a "delicate balance" between the rights of copyright proprietors and copyright users. This balance is disrupted when state law is permitted to enlarge the rights of copyright proprietors at the expense of copyright users. Although attempts at altering the delicate balance struck by copyright law should fail under the doctrine of preemption, a recent decision from the Seventh Circuit ${ }^{12}$ illustrates that courts sometimes fail to appreciate the preemptive force of copyright, even when the subject contract is intended to defeat users' rights validated by on-point United States Suprenie Court precedent.

Article 2B purports to reniain "neutral" on questions of federal preemption based on encroachments by contract on copyright doctrine. However, by making provisions of software licenses presumptively enforceable while providing no limitations on overreaching contract terms that proprietors nray unilaterally decide to impose, Article $2 \mathrm{~B}$ facilitates known practices designed to alter the "delicate balance" and places the costs of defending the proper bounds of copyright on copyright users. This result is neither desirable nor necessary.

Article $2 \mathrm{~B}$ can help niaintain rather than undo the delicate balance that lies at the core of copyright by giving some guidance as to which types of constraints are at odds with copyright and therefore preempted. But absent appropriate corrections to its current instantiation, it is likely to result $\mathrm{m}$ the use of contracts-backed up by the force of the U.C.C. - systematically to displace the rights of users. It is important to appreciate that such resort to contract does not represent the election of contract protection in lieu of copyright. Instead, it represents the use of contract to distort copyriglit, grotesquely at tinies. Proprietors who might take advantage of Article 2B do not opt out of copyright protection; they enjoy all of its benefits plus all of the benefits that can be accorded by contracts diminishing the rights of users. We suggest, accordingly, that if Article 2B is to be enacted, it first be amended to evince greater sensitivity towards proscribing certain contracting practices that are inconsistent with sound copyright policy.

This Article proceeds in four Parts. Part I reviews the existing relationship between federal copyright law and state contract doctrine. Part II argues that copyright law already provides adequate protection to copyright owners who distribute software, and that attempts by copyright owners to enlarge their rights by contract conflicts with copyright law's concern for the rights of users. Part III undertakes a critical discussion of the Seventh Circuit's decision in ProCD, which upheld a "shrinkwrap" license that extended contractual protection against copying to subject matter that the Supreme Court has already declared uncopyrightable. Finally, Part IV critiques the failure of Article 2B,

12. ProCD, 86 F.3d 1447. See discussion infra Part III. 
under a guise of "neutrality," to take into account the rights of information users and the demands of federal law.

\section{I}

The Inevitable Coexistence of Copyright and Contract

\section{A. Transfer}

Copyright is, at heart, a creature of the Constitution and the Copyright Act. But ownership and exploitation of copyright are structured at every turn by contract. Unlike the monistic copyright system of German law, under which authors may never separate themselves from ownership of the indivisible whole, U.S. copyright law follows a regime of infinite divisibility. ${ }^{13}$ The statute itself contemplates transfers in the nature of "an assignment, mortgage... or any other conveyance, alienation, or hypothecation of a copyright or of any of the exclusive rights comprised in a copyright ...."14

One salient feature of the terms just quoted is the failure of the Copyright Act to define any of them. Given that the United States Code nowhere contains an established common law as to what constitutes a "mortgage," resort to state law to determine the nature of that device, as well as like hypothecations of ownership, appears inevitable.

Imagine for a moment that Atalanta transfers ownership of her copyright to Busiris, who gives it to Cadmus, who in turn mortgages it to Dindyma Bank, which then forecloses and sells out to Erigone. In a worst-case scenario for Erigone, her ownership of the copyright could be subject to challenge on the grounds that Atalanta was a minor who may disaffirm the contract because it was not confirmed by the state court of her domicile; ${ }^{15}$ that Busiris (who had previously been declared insane and placed under the control of a conservator appointed by the courts of the state in which he lived) was not bound because his legal guardian failed to sign the purported grant; that Cadmus neglected to

13. Compare Adolf Dietz, Germany $\S 4[2][a]$, in INTERNATIONAL COPYRIGHT LAW AND Practice (Melville B. Nimmer \& Paul Edward Geller eds., 1998) with 3 Melville B. Nimmer \&

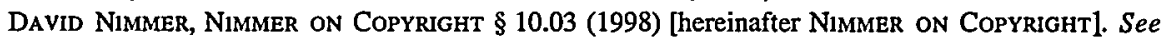
generally Thomas F. Cotter, Pragmatism, Economics and the Droit Moral, 76 N.C. L. REv. 1, 8-10 (1997) (contrasting German monistic system with U.S. copyright). The Act also explicitly contemplates that the copyright owner may transfer the copyright bundle or any piece of it by "any means of conveyance." 17 U.S.C. $\$ 201$ (d)(1) (1994). An exception to the general rule of alienability is the very limited rights of visual artists, conferred by a 1990 amendment. See 17 U.S.C. $\S 106 \mathrm{~A}(\mathrm{e})(1)$ (1994). To this highly circumscribed extent, U.S. law resembles the French notion of inalienability in the moral rights sphere. See 3 NIMMER ON COPYRIGHT, supra note 13, §\$ 8D.01[A], 8D.06[D]. Yet even here it departs from the French tenplate of imprescriptibility, by allowing waivers of moral rights. See 17 U.S.C. § 106A(e) (1994).

14. 17 U.S.C. $\$ 101$ (1994).

15. See Cal. Fam. Code $\$ \$ 6750-6751$ (West 1994). See also Baez v. Fantasy Records, Inc., 144 U.S.P.Q. 537 (Cal. Super. Ct. 1964) (disaffirming contract by minor reaching her majority). 
perfect the mortgage in the manner required by his own state's law; and that Dindyma Bank had previously dissolved, thereby rendering its purported transfer nugatory. ${ }^{16}$

In each of those particulars, the battle is waged primarily under state law. ${ }^{17}$ To take the case of an individual committed to an insane asylum, for example, it is difficult to find any governing federal law, and thus to resist wholesale descent into the minutiae of the subject state's ordinance. In the balance of the other instances, federal law likewise does not directly speak to the question of who holds the capacity to enter into a contract. Erigone therefore faces the prospect of lengthy explorations of state law in order to validate her federal copyright claims. The best she can hope for is the application not of the particular law of the state in which Atalanta, Busiris, Cadmus, and the rest chanced to live, but instead a general notion of common law as applied throughout the several states. ${ }^{18}$ But even that victory does not invoke the application of federal norms; instead, it looks to an abstract notion of state law. ${ }^{19}$

\section{B. Works for Hire}

As the above hypotheticals demonstrate, the symbiotic relationship between copyright and contract continues throughout the life of a copyright. Moreover, it can begin even before copyright birth, the moment an original work of authorship is fixed for the first time in a tangible medium of expression. ${ }^{20}$ In this guise, it arises as a factor in defining who the "author" is and thus in determining the identity of the initial

16. "What if there is no 'proprietor' at the time of renewal, because the corporation in which copyright vests has become defunct? Under general principles, it would see[m] necessary to trace disposition of assets under state corporate law to locate the proprietor in that instance." 3 NIMMER ON COPYRIGHT, supra note $13, \$ 9.03$ n.6.1.

17. Another oft-litigated issue in the copyright sphere arises when a party to a copyright contract attempts to rescind it, for non-performance or otherwise. The determination of whether the combined circumstances warrant rescission arises either under the law of the state in which the contract was executed (or the parties were located) or more broadly under the general state common law of contracts. See 3 Nimmer ON COPYRIGHT, supra note 13, § 10.15[A] (collecting cases).

18. See id. at $\$ 9.03$ n.6.1 (citing Fleming v. Charles L. Harney Constr. Co., 177 F.2d 65, 70 (D.C. Cir. 1949) (construing Surplus Property Act of 1944 such that corporate "dissolution cannot be distinguished from the death of a natural person," and following general common law rather than rule of state of incorporation)).

19. Whether the subject law tracks that of an individual state or a more generalized notion of state law is of no moment to the discussion that follows. Nonetheless, it strikes us that copyright law tends to focus on the "brooding omnipresence" of common law, rather than on the particulars enacted in any given jurisdiction. See, e.g., Community for Creative Non-Violence v. Reid, 490 U.S. 730 (1989) (determining status of "employee" under Copyright Act by reference to the factors set forth in the Restatement (Second) Of Agency). Cf. Erie R.R. Co. v. Tompkins, 304 U.S. 64 (1938) (rejecting federal "general law" as rule of decision in diversity cases).

20. See 17 U.S.C. \$ 102(a) (1994). 
"copyright owner."21 Ordinarily, the author is the efficient cause of parturition, that is, the human being(s) who gave birth to the work. The Act departs from the default rule, however, when a preexistent contract applies to certain categories of specially commissioned works "if the parties expressly agree in a written instrument signed by them that the work shall be considered a work made for hire."22 Thus, both at gestation and throughout its life, a copyright is owned according to a complex scheme deriving in large part from state law.

\section{Sale, Rental, Lease}

But it is not solely the question of ownership over which state law governs. Copyright exploitation, too, can often turn on distinctions that equally derive from state laws. In this respect, we depart from the intangible essence of the copyrightable work and move to the tangible good in which it may be embodied..$^{23}$ Consider that copyright owners enjoy the exclusive right "to distribute copies or phonorecords of the copyrighted work to the public by sale or other transfer of ownership, or by rental, lease, or lending." 24 Moreover, one in possession of a lawfully made copy "is entitled, without the authority of the copyright owner, to sell or otherwise dispose of the possession of that copy ...."25 As was the case with respect to "mortgage" and the rest, neither the Copyright Act itself nor other applicable features of federal law define when a "sale" or "rental" or act of "lending" of a physical item has taken place. For these questions as well, resort to state law appears inevitable. ${ }^{26}$

In sum, federal copyright doctrine leaves to state law the vast bulk of issues concerning contracts affecting copyright. It follows that state contract law (and cognate doctrines arising under state law) determine to a great extent the destiny of a copyrighted work and the physical object in which it is embodied. Those state rules play a critical role in maintaining the "delicate equilibrium" between the rights of copyright

21. "Initial Ownership-Copyright in a work ... vests initially in the author or authors of the work.” 17 U.S.C. § 201(a) (1994).

22. 17 U.S.C. $\$ 101$ (1994). In the Seventh Circuit, the contract must indeed be prenatal. See Schiller \& Schmidt, Inc. v. Nordisco Corp., 969 F.2d 410, 413 (7th Cir. 1992). In the Second Circuit, a more ameliorative rule prevails. See Playboy Enters., Inc. v. Dumas, 53 F.3d 549, 559 (2d Cir. 1995) (citing with approval 1 NIMMER ON COPYRIGHT, supra note $13, \S 5.03[\mathrm{~B}][2][\mathrm{b}]$ ).

23. See 17 U.S.C. $\$ 202$ (1994).

24. 17 U.S.C. § 106(3) (1994).

25. 17 U.S.C. $\$ 109$ (a) (1994). This provision-imprecisely labeled the "first sale" doctrineplays a large role below. See infra Section III.B.

26. One case apparently holds that perfume with a copyrighted label, although imported from abroad, was in fact "sold" within the United States under the pertinent provision of the Uniform Commercial Code. See Cosmair, Inc. v. Dynamite Enters., Inc., 226 U.S.P.Q. 344, 347 (S.D. Fla. 1985). That case treats gray market importation, a subject that the Supreme Court addressed in Quality King Distributors, Inc. v. L'Anza Research International, Inc., 118 S. Ct. 1125 (1998). 
holders to reap the rewards of their intellectual property and the rights of the public to unimpeded advancement of knowledge and expression.

\section{Contract Formation}

Consonant with the traditional interplay between state contract law and federal copyright law, the U.C.C. can help defme the mechanics of contract law im the context of contemporary transactions. For example, Article $2 \mathrm{~B}$ creates rules to govern electronic contracting and provides that the fact that a contract is in electronic form does not alter or reduce its effect, validity, or enforceability. It gives binding weight to electronic signatures, and it sets forth rules for determiming who shall be held responsible for electronic messages. ${ }^{27}$ All of these factors may arise in the context of an electronic license of copyrightable subject matter-an electronic contract for distribution rights in a book or motion picture, for example-which parties modify by e-mail and sign using digital signatures. Because federal copyright law, standing alone, is silent as to whether such a contract is enforceable, the U.C.C. can usefully fill the doctrinal gap in this and like instances. Article $2 \mathrm{~B}$ therefore can provide important support to the goal of maintaining copyright's "delicate equilibrium" in the digital age.

\section{E. Limits of Contract Rights}

Nonetheless, federal abdication in favor of determinations of contract principles under state law has its limits. In certain particulars, the Copyright Act itself sets forth some governing parameters applicable to contracts and other inatters typically reserved to determination under state law. When those circumstances obtain, federal law controls, notwithstanding contrary state doctrines..$^{28}$

One example is so pronounced as to have virtually escaped notice. Undoubtedly the most well-known aspect of Anglo-American contract law is its requirement of a quid pro quo-the doctrine of consideration. ${ }^{29}$ It is doubtful that the law of any state in the union dispenses with that general requirement..$^{30}$ Were it applicable to the copyright sphere, that doctrine would invalidate grants of copyright ownership unrequited

27. See U.C.C. $\$$ 2B-113-116 (Draft, Mar. 1998).

28. For a lengthy discussion of copyright contracts in contrast to state law doctrines of community property, see generally David Nimmer, Copyright Ownership By the Marital Community: Evaluating Worth, 36 UCLA L. REv. 383 (1988).

29. Thus, A's promise to $B$ to pay $\$ 1000$ if $A$ cannot run a marathon in under 5 hours is a nullity. But B's agreement to give A a peppercom if A timely completes the marathon probably resuscitates the contract. See Restatement (SECOND) of Contracts $\$ 17$ (1979).

30. Of course, exceptions exist under state law. Thus, A's promise to pay $\$ 1000$ to the United Way without any return obligation is often enforceable under an exception to the doctrine of consideration for promises to make charitable contributions. 
by the grantee. ${ }^{31}$ Yet "[n]otwithstanding that feature of state law, no consideration is necessary under federal law to effectuate a transfer of copyright ownership that does not purport to require consideration." 32 (Nonetheless, one must acknowledge that few, if any, cases have tested the boundary of consideration-less copyright grants, presumably because grantees of valuable copyrights invariably recite the delivery of "\$10 and other good and valuable consideration" in order to escape serving as a test case. ${ }^{33}$ )

The most prominent example of federal contract requirements trumping contrary state doctrine that has received treatment in published decisions is the Act's requirement that any transfer of copyright ownership ${ }^{34}$ "is not valid unless an instrument of conveyance... is in writing and signed by the owner of the rights conveyed ...."3s Even if state law validates oral grants - attested by the grantor before the mythical bench of fifty bishops, for example-that law must bow to the superior force of the federal enactment. ${ }^{36}$

Another example of the same phenomenon-though this one has gone unlitigated-arises under copyright's termination-of-transfers doctrine, which allows authors a "second bite of the apple" for works that they long ago sold, gave away, or otherwise alienated. ${ }^{37}$ In particular, the Act itself provides with respect to transfers of copyright ownership that, following the lapse of a set period," "[t]ermination of the grant may be effected notwithstanding any agreement to the contrary, including an agreement to make a will or to make any future grant." 39 Accordingly, a contract not to exercise an author's termination rights

31. Recall that Busiris gave the copyright hypothesized above to Cadmus gratis. Were a requirement of consideration applicable to copyrights, an additional quiver would accrue to the bow of Erigone's enemies.

32. 3 NIMMER ON CoPYRIGHT, supra note $13, \S 10.03$ [A][8].

33. See, e.g., id. Form 21-21.

34. Note that such transfers definitionally exclude nonexclusive licenses under copyright. See 17 U.S.C. $\S 101$ (1994).

35. 17 U.S.C. $\$ 204(a)$ (1994).

36. See, e.g., Valente-Kritzer Video v. Pinckney, 881 F.2d 772, 775-76 (9th Cir. 1989) (holding preempted claims for breach of oral contract and tortious breach of contract); Marshall v. New Kids On The Block Partnership, 780 F. Supp. 1005, 1009 (S.D.N.Y. 1991) (rejecting claim as one for breach of an oral contract rather than for infringement of the copyright orally transferred); Library Publications, Inc. v. Medical Econs. Co., 548 F. Supp. 1231, 1234 (E.D. Pa. 1982) (finding unenforceable oral agreement for transfer of copyright ownership), aff'd, 714 F.2d 123 (3d Cir. 1983).

37. See 17 U.S.C. $\$ \S 203,304$ (c) (1994). More technically, the Supreme Court has labeled the reversion-of-renewals doctrine as a "second chance" and, correlatively, the termination-of-transfers device here under consideration a "third opportunity" for authors to profit from works that they had long ago alienated. Stewart v. Abend, 495 U.S. 207, 220, 225 (1990).

38. In brief, grants effectuated before 1978 are subject to termination following 56 years of the work's copyright subsistence; grants effectuated thereafter are subject to termination 35 years after the work's publication. See generally 3 NIMMER ON COPYRIGHT, supra note $13, \S 11.05$.

39. 17 U.S.C. $\S \S 203(a)(5), 304(c)(5)(1994)$. 
may be fully operational under state law, yet the superior force of federal law nonetheless bars its enforcement, effectively rendering it a nullity. ${ }^{40}$

Much confusion arises in attempting to reconcile these strands. ${ }^{41}$ As an example, consider the ruling that when Congress used the term "children" in the context of termination of pre-1978 transfers ${ }^{42}$ it intended to adopt antecedent state family law definitions as to who qualifies for that label, ${ }^{43}$ whereas when Congress used the same word in the same Act to apply to termination of post-1978 transfers, it intended to adopt a federal definition incorporated into the Copyright Act itself. ${ }^{44}$ The court reached that result by attempting to follow Congress's will in enacting a given provision of the Copyright Act. ${ }^{45}$ As we shall see, that desideratum furnishes the touchstone for proper analysis in the journey that follows.

\section{II \\ Contract Need Play No Role in Protecting Copyright Rights}

Though Article 2B, as noted above, can usefully serve a complementary role to copyright, there is one significant function for which Article $2 \mathrm{~B}$ is not needed: to protect the copyright interests of copyright proprietors, especially in the context of mass market distribution of software, one of the paradigmatic transactions under Article $2 \mathrm{~B}$. Contrary to the claim that Article $2 \mathrm{~B}$ is needed to protect copyright interests in that context, existing copyright law adequately protects those owners

40. See generally 3 NiMmER ON COPYRIGHT, supra note $13, \S 11.07$.

41. As the drafters of Article 2B comment, "The relationship between federal law and state contract law is complex." U.C.C. $§ 2 B-105$ reporter's note 1 (Draft, Mar. 1998). In our opinion, even the Courts of Appeals have erred on both sides of the issue under discussion, that is, state contract law control over disposition of copyrights. The Ninth Circuit misconstrued Congress's will in holding doctrines of state contract law preempted in Rano v. Sipa Press, Inc., 987 F.2d 580 (9th Cir. 1993), criticized in 3 NIMMER ON CopYrIGHT, supra note 13, $\S 11.01[\mathrm{~B}]$. The Second Circuit, by contrast, inappropriately failed to advert to Congress' will to allow even oral grants of nonexclusive licenses, see infra note 47, by disallowing them under state law in Grappo v. Alitalia Linee Aeree Italiane, S.p.A., 56 F.3d 427, 431-32 (2d Cir. 1995), criticized in 3 NIMMER on CoPYRIGHT, supra note 13, $\$$ $10.03[\mathrm{~A}][8]$.

42. On the termination-of-transfer doctrine, see the preceding paragraph and its footnotes.

43. The rationale here stems from DeSylva v. Ballentine, 351 U.S. 570 (1956), which looked to state family law in the reversion of renewal context. Yet even this Supreme Court ruling is not unlimited, as the Court indicated that applicable state law would not be followed to the extent that it defined children "in a way entirely strange to those familiar with its ordinary usage." $I d$. at 581 .

44. See Stone v. Williams, 970 F.2d 1043, 106465 (2d Cir. 1992), cert. denied, 508 U.S. 906 (1993), discussed in 3 NIMMER ON COPYRIGHT, supra note $13, \S 11.03$ [A][2][a].

45. The court followed the logic that the provision applicable to pre-1978 grants was intended to continue prior law on the subject, which had been subject to the Supreme Court's gloss in DeSylva. By contrast, the provision applicable to grants entered on January 1, 1978, and thereafter was created out of whole cloth; in this instance, Congress presumably wished to apply the definition of "children" that it incorporated into the same new enactment. See Stone, 970 F.2d at 1064-65. 
when they distribute copyrighted mass market software, even in a world in which shrinkwrap agreements are not deemed enforceable contracts. ${ }^{46}$ That conclusion follows because the exclusive rights granted under the copyright laws effectively preclude use of computer software-to the extent the Constitution and Congress accord a monopoly thereinwithout the express or implied permission of the copyright owner.

\section{A. Enforceability of Unilateral License Terms}

When a copyright owner distributes its software, it is free to grant a license extending only to specified uses, while excluding others. Moreover, any such license does not require a bilateral contract. A simple, unilateral statement by the copyright owner of the scope of its license suffices. ${ }^{47}$ In most cases, use beyond the scope of that license constitutes actionable copyright infringement under existing copyright law. ${ }^{48}$ To the extent that any such use beyond the scope of the unilateral license is not copyright infringement-for instance, because it constitutes fair use under section 107-state contract law cannot produce a different result.

Several hypotheticals illustrate the ability of publishers to protect their intellectual property rights when engaging in mass distribution of software. First, Procne picks up the latest copy of SuperSmart 321, a nifty spreadsheet program, at CompUSA. She purchases the program without openimg the box and takes it home. Unlike most software products, SuperSmart 321 contains no license terms of any kind.

In this hypothetical, existing copyright law permits Procne to do exactly what a typical publisher and typical buyer would contemplate: use the software on a single computer and make a backup copy. Because Procne purchased a copy of the software, she clearly falls within the ambit of the statutory section securing rights to those owners. ${ }^{49}$ She thus is entitled to copy the software onto her computer's hard drive in order to run it, ${ }^{50}$ as well as to make a tangible backup copy. ${ }^{51}$ Any further copying of the software-and thus, effectively, use on any other computer system-constitutes copyright infringement unless

46. Other interests of the copyright owner, such as the right to a royalty stream, limitations of liability, and limitations of warranties, may, by contrast, require enforceable contracts for protection. It is precisely these other interests that Article 2B properly serves.

47. See 3 Nimmer on Copyright, supra note $13, \S 10.03$ [A] (citing cases). Indeed, even an oral stateinent may be sufficient to grant a nonexclusive license. See id.

48. See, e.g., S.O.S., Inc. v. Payday, Inc., 886 F.2d I08I, 1088 (9th Cir. 1989) ("[Clopyright licenses are assumed to prohibit any use not authorized.").

49. See 17 U.S.C. $\$ 117$ (I994) ("[I]t is not an infringement for the owner of a copy of a computer program to make... another copy or adaptation of that computer program.... as an essential step in the utilization of the computer program in conjunction with a machine....').

50. See I7 U.S.C. $\$ 117(\mathrm{I})$ (1994).

51. See 17 U.S.C. $\$ 117(2)$ (1994). 
excused, for instance as a fair use. ${ }^{52}$ Thus, copyright law alone affords the publisher of SuperSmart 321 ample power to prevent Procne from making or distributing improper copies of the software, or even duplicating the software on inultiple machines in her home or office. No bilateral contract is necessary to protect the software publisher's rights.

Second, Pandion picks up the latest copy of SuperSmart 321 by purchasing it via the Internet. He pays for it with a credit card and downloads it to the hard drive of his computer. Once again, the results will be effectively the same as above, even without a written license agreement. Pandion still owns the copy of the computer program on his hard drive and is authorized to use it (but not reproduce it except for backup purposes) pursuant to the statutory sections invoked above..$^{53}$

Third, Itys purchases a "10 User Pack" of Virulator, a software package that locates all computer viruses on a user's hard drive, removes them and e-inails thein to Iraq. He installs the software on the network server in his office. The envelope containing the CD-ROM, as well as the install screen, inform Itys that: "This software product is licensed for imstallation on a network server, to be accessed by no more than 10 users simultaneously. All other rights are reserved."

Under existing copyright law, the manufacturer's 10-user limitation is enforceable regardless of whether state law treats the above notice as part of a binding bilateral contract. ${ }^{54} \mathrm{~A}$ copyright owner may grant a non-exclusive license by any words or conduct tending to show such a license. ${ }^{55}$ Thus, by virtue of the above language, the publisher of Virulator has expanded Itys's right to use his copy on a single

52. See 17 U.S.C. $\$ 107$ (1994).

53. See 17 U.S.C. $\$ 117$ (1994). One could argue in this context that Pandion is not the "owner of a copy of a computer program" under section 117 because a "copy" under the Copyright Act is a material object in which a work is fixed and Pandion did not purchase a material object (the hard disk), but only the data comprising the computer program. In light of the fact that Pandion was authorized to download the data to his hard drive (or to another conventional storage medium such as a diskette), it is more reasonable to conclude that Pandion has purchased a copy of the program, that is, a tangible medium in which the work is embodied. See, e.g., MAI Sys. Corp. v. Peak Computer, Inc., 991 F.2d 511, 518-519 (9th Cir. 1993). See infra Section II.B. But even accepting the proposition that what is purchased must meet all the requisites of a "copy" before downloading begins, Pandion would seem to have a powerful argument that, by virtue of purchasing the software on-lime, he received an implied license to use what he paid for. See, e.g., Effects Assocs., Inc. v. Cohen, 908 F.2d 555, 558-59 (9th Cir. 1990) (implying license from delivery, without restriction, of special effects footage for use in film). In the absence of any terms to the contrary communicated at the time of the liccnse, Pandion should have the right to use the software for its ordinary and intended purpose, that is, on a single computer. For an extended treatment, see David Nimmer, Brains and Other Paraphernalia of the Digital Age, 10 HARv. J.L. \& TeCH. 1 (1996) [hereinafter Nimmer, Brains].

54. The U.C.C. drafters lean in the same direction. See U.C.C. \$ 2B-111 reporter's notes (Draft, Mar. 1998) (restricting usage for consumers only enforceable under copyright law without any requirement for assent).

55. See 3 Nimmer on Copyright, supra note $13, \S 10.03$ [A]. 
machine $e^{56}$ to include making one copy on a server and up to nine other copies in the random access memory (RAM) of client computers. If Itys were to allow 20 users to access the software, the copies existing in the RAM of machines 11-20 would be unlicensed and hence infringing. ${ }^{57}$ The publisher thus has the lever it needs to preclude unlicensed use, without obtaining Itys's enforceable promise via the U.C.C. not to use the software on more machines than authorized.

Fourth, after her company's IPO, Philomela decides that she has grown bored with life in the Silicon Valley, exercises her stock options and moves for a year to Tahiti (after thrashing Thrace). Before she moves, she posts an ad on the Internet offering to rent her copy of MegaCAD 3D, an elaborate $\$ 10,000$ software package. Tereus has an eight-month project for which he desperately needs MegaCAD. He spots Philomela's ad and jumps at her offer. Tereus pays $\$ 1,000$ for a year's use of the disks. Can the publisher of MegaCAD prevent this transaction?

Under existing copyright law, Philomela may not rent or lease her copy of the software..$^{58}$ Similarly, Tereus is not entitled to use the software, as to do so would involve copying the software into the computer's RAM, which constitutes infringement in the absence of a license. ${ }^{59}$ Thus, the publisher has a viable copyright infringement claim against Philomela and Tereus. An enforceable promise by Philomela not to rent her software is unnecessary here, too.

Fifth, Bacchus needs software to help him manage a fleet of trucks for his party-hearty business. Like all good small businessmen, Bacchus is cost-conscious. He finds a shareware package on the Internet, OINOS, which looks like it will do the trick. Bacchus downloads the OINOS software, reads the license, which provides that he may use the software for his own business purposes, but cannot modify or redistribute it. He pays the $\$ 19.95$ registration fee and uses the software. Two years later, Bacchus realizes he needs an integrated system to link his truck management software with the rest of his business. He hires an independent software consultant to build such a system. Because he loves OINOS so much, Bacchus specifically asks the consultant to make his new system work just the same way. The consultant, who is convinced he is underpaid, takes a shortcut and includes a modified version of some of the

56. That is, the default right that Itys would have in the absence of the subject language under 17 U.S.C. § 117.

57. See MAI, 991 F.2d 511 (stating that loading a copy of software into computer's RAM constitutes creation of a "copy" under the Copyright Act).

58. See 17 U.S.C. \& 109(b)(1)(A) (1994).

59. See, e.g., MAI, 991 F.2d 511. Tereus cannot avail himself of the benefits of section 117 because he is not the "owner" of the copy he wishes to use, having simply rented it. See 17 U.S.C. $\S 202$ (1994). 
OINOS code in the system he has been fermenting. Ultimately, the new system is so successful that Bacchus markets it to other trucking businesses.

Can the author of OINOS complain? Of course. It does not matter whether the license agreement that accompanied the OINOS software is deemed an enforceable contract. Under existing copyright law, Bacchus had no right to have the OINOS software modified or incorporated into another system, thereby creating unauthorized derivative works. ${ }^{60}$ Nor did he have the right to reproduce it for distribution to others, whether as part of a new systein or separately. Article $2 \mathrm{~B}$ adds nothing of substance to the rights of OINOS's owner.

One could spin out numerous other hypotheticals involving typical modes of software distribution and reach the same result. At least for the modes of software distribution used today, copyright law provides all the teeth a publisher needs to control use and dissemination of her work. No ersatz shark via contractual promise is necessary to enforce these rights.

The conclusion that contract is not needed to protect copyright interests further pertams when we consider other forms of distribution in the digital realm. Consider, for example, the Divx (Digital Video Express) technology for distribution of movies, which may be upon us in the very near future. Divx operates like a DVD disk containing a inovie, except that the encryption software included on the Divx disk limits the user to playing the movie for a set number of days following the first time she plays the disk. ${ }^{61}$ Once the initial viewing period expires, the owner of a Divx disk can obtain additional play time, or in some cases convert the disk to unlimited play, for a fee. ${ }^{62}$ What if a studio sellimg inovies on Divx disks feels it needs an enforceable promise by the buyer not to attempt to circuinvent the lockout technology built into the software?

Although one can appreciate the desire of the studio to seek any and all legal protections it can, the copyright laws of today (and certainly those of tomorrow) should prove more than adequate to protect the studio's interest, even absent the proposed contract..$^{63}$ Modifying the

60. See 17 U.S.C. $\$ 106(2)$ (1994).

61. See Digital Video Express, LP, About Divx Technology (visited Sept. 13, 1998) $<$ http://www,divx.com/about_divx_divxtechnology.htm>.

62. See id.

63. To a certain extent, the best protection for the studio will come from the quality of its technology. Regardless of whether copyright law or contract law forms the basis of a claim, suing individual buyers of movies for making illicit copies on behalf of relatives or friends is unlikely to be economically worthwhile, even if one somehow concluded that it were sound business practice. Pursuing large-scale pirates (including those who sell devices or software to defeat copy protection) can be done as effectively, if not more, under the copyright laws as under contract. See Cable/Home Communication Corp. v. Network Prods., Inc., 902 F.2d 829 (11th Cir. 1990). 
Divx software to defeat the lockout (assuming, for the sake of argument, it were technically possible) likely would involve either unauthorized reproduction of at least a portion of the copyrighted work, or the creation of an unauthorized derivative work. Either way, copyright infringement liability would result. Moreover, any doubt about the impropriety of defeating anti-copying technology will likely be laid to rest by pending federal legislation. ${ }^{64}$ Thus, even on the so-called bleeding edge of technology, we find it difficult to see a need for state law protection of copyright rights in connection with the mass-market distribution of copyrighted works.

\section{B. The Conflation of Licensing with Distribution}

The considerations set forth above assimilate software contracts to traditional means of copyright exploitation. The Article 2B posits "two distinct frameworks" in this regard. ${ }^{65}$ It is worth reviewing the drafters' view of the matter at some length:

The first [framework] mvolves use of a master copy and is common in the movie industry and in software contracts. Under this framework, a "distributor" receives access to a single master copy of the information work and a license to make and distribute additional copies or to make and publicly perform a copy. For example, Correl Software may license a distributor to allow its software to be loaded into the distributor's computers or video games. The contract will contain a number of terms. Correl may limit the distributor to no more than 1,000 to be distributed only in the computers and only if subject to an end user license. Since both the making copies of and the distribution of copies are within the scope of the owner's copyright, acts that go outside the contractual limitations are infringements as well as contractual breaches.

An alternative methodology uses actual copies of the software. Here, for example, Quicken may license a distributor to distribute its accounting software in packages provided to the distributor by Quicken. A license is used in the software industry here, although some other industries may sell copies to the distributor for resale. In the license, the distributor may be allowed to distribute copies to retailers, provided that certain conditions are met, such as terms of payment, retention of the original packaging, and making the eventual end user distribution occur subject to an end user license. Since the distribution right is an exclusive right in copyright law, distributions outside the license infringe the copyright.

64. See WIPO Copyright Treaties Implementation Act, H.R. 2281, 105th Cong. (1997). See generally David Nimmer, Aus der Neuen Welt, 63 Nw. U. L. Rev. (forthcoming 1998).

65. U.C.C. art. 2B Preface at 7 (Draft, Mar. 1998). 
In both sequences, the information product eventually reaches an end user. If it does so in an ordinary chain of distribution complying with the distribution licenses, the end user is in rightful possession of a copy. If the distribution involved sales of copies, nothing more is required. The end user is the owner of the copy. Copyright law spells out limited rights that flow to the owner of the copy (e.g., to distribute it, make a back-up if it is software, inake some changes essential to use if [sic] its software). There is no direct contractual relationship between the copyright owner and the "end user."

If, however, the copyright owner elected a licensing framework, given the structure of the transactions, the end user's right to "use" (e.g., copy) the software depends on the end user license. Typically, this is characterized as a license from the producer to the end user. It creates a direct contractual relationship that would not otherwise exist and which, in light of concepts of privity, might not be implied as between these parties. The contract, then, at this point, jumps past the chain of distribution and creates a direct link to the producer by the end user. It is also, in this sequence, the only contract that enables the end user to make copies of the software in its own machine. ${ }^{66}$

Given that, as the hypotheticals set forth in the previous subsection of this Article reveal, ${ }^{67}$ copyright law itself regulates the activities of remote purchasers of software, why does Article 2B attempt to create " a direct link to the producer by the end user" ${ }^{68}$ The answer stems from the language italicized above. Through these various references, the draft posits a framework that falls short of a sale, constituting merely a license.

The first two paragraphs quoted above contrast "access to a single master copy" with the "alternative methodology [that] uses actual copies of the software." It is indeed possible to imagine access without inaking actual copies. For instance, instead of purchasing diskettes containing Microsoft Word 97 and loading it onto your hard drive, you could pay a monthly fee to log onto the Microsoft web site and create and edit documents there. At the end of each session, you would download your text and save it, but you would never obtain any copy of the coinputer program itself. That scenario indeed involves access without the alternative of obtaining actual copies. By contrast, if you do download Word 97 onto your hard drive, then you have already moved to the

66. Id. (emphases added, except for sixth emphasis (“these parties”)).

67. See supra Section II.A.

68. Elsewhere, the draft goes even further: "The form establishes for the first time a relationship between the copyright owner and the end user that may be central to the end user's right to use the information." U.C.C. § 2B-508 reporter's note 5 (Draft, Mar. 1998). 
realm in which copyright law's first-sale doctrine applies. ${ }^{69}$ This realm is entered, moreover, regardless of whether the label "license" applies to Microsoft's granting of rights in the copyright to the program.

For these purposes, it is vital to differentiate between tangible and intangible property. ${ }^{70}$ When a software publisher distributes its product, it certainly does not part with copyright ownership.71 Instead, the only matter under examination is whether it has parted with ownership of the physical media incorporating that software. Article $2 \mathrm{~B}$ evidently takes the view that a status short of sale exists - which it calls "licensing"whereby end users nonetheless acquire full dominion over the tangible property that comes into their safekeeping.

One line of cases cited by the drafters of Article $2 \mathrm{~B}$ apparently vindicates the existence of this type of "licensing" framework. It is exemplified by Microsoft Corp. v. Harmony Computers \& Electronics, Inc., ${ }^{72}$ which arose over the distribution of Microsoft's MS-DOS and Windows software. The facts in the case are unclear. It may be that some of the software at issue in the case was pirated. To that extent, the subject diskettes were clearly unauthorized, outside the safe harbor of the first-sale doctrine, ${ }^{73}$ and thus rightfully subject to seizure and suppression. ${ }^{74}$ On the other hand, the opinion can also be read to arise from a factual posture in which Microsoft produced copies of Windows software, whieh it then distributed to Original Equipment Manufacturers (OEMs). The OEMs then disposed of the copies in their possession, as they were entitled to do under the first-sale doctrine. To the extent that the case implicated the first scenario, it is uninteresting-counterfeit products are clearly not entitled to further distribution. But the second scenario is evidently the basis for the Article $2 \mathrm{~B}$ drafters' citation to the case. ${ }^{75}$ It is accordingly necessary to evaluate it from that standpoint.

Microsoft $v$. Harmony rejected the defendants' first-sale defense on the basis that "Microsoft only licenses and does not sell its Products."76 What does that holding mean? To appreciate its import, the buzzwords "licenses" and "Products" must be unscrambled.

69. See 17 U.S.C. $\$ 109$ (1994).

70. See 17 U.S.C. $\$ 202$ (1994).

71. Only to the extent that the publisher assigns the copyright or exclusively licenses it (or engages in other hypothecations, such as mortgages) does a transfer take place. In a typical mass market situation, no such transfer of copyright interests has occurred.

72. 846 F. Supp. 208 (E.D.N.Y. 1994), cited in U.C.C. $\S 2 B-508$ reporter's note 5 (Draft, Mar. 1998).

73. See 17 U.S.C. $\$ 109$ (1994) (limiting protection to copies "lawfully made under this title").

74. See Harmony, 846 F. Supp. at 212. An additional problem for the defense in that case was an inability to trace its precise distributions back to initial productions by Microsoft. See id. Given that the request was for a preliminary injunction, it is not surprising that the factual record before the court at that time was sparse.

75. See U.C.C. \& 2B-508 reporter's note 2 (Draft, Mar. 1998).

76. 846 F. Supp. at 213. 
License of tangible medium. If the underlying facts were that Microsoft leased diskettes or CD-ROMs to end users and sent its agent to collect those physical media at a time specified in the lease, then no sale of those physical products occurred. Under those assumed facts, Microsoft had not parted with possession of a physical copy. On that basis, no sale occurred and copyright's first-sale doctrine does not come mto play. ${ }^{77}$ That is one possible sense in which Microsoft may have "licensed" its "Product."

License of copyrighted work embodied in tangible medium. By contrast, if the underlymg facts were that Microsoft issued only a license to its MS-DOS and Windows products, but did so through the sale or other permanent disposition of tangible items embodying those products, then the first-sale implications are wholly different. Imagine, for example, that Microsoft gave OEMs diskettes with the intent that they would be distributed to end users who could discard the diskettes in the trash or erase and reuse them ${ }^{78}$-so long as the users did not reproduce the subject software. ${ }^{79}$ Under this latter scenario, a sale of the physical medium has occurred, and its purchaser is clothed under the Copyright Act with the rights belonging to rightful owners of physical property, subject to all of the obligations under the Act that are reserved to Microsoft of exercising copyright dominion. This is the second sense in which Microsoft may be said to "license" its "Product."

These two paradigms are illustrated by the evolution of motionpicture exploitation. Film owners have the option not to sell their works, but only to "license" them. For decades, the motion-picture studios followed exactly that course, jealously guarding ownership of the celluloid primts and only renting them to theaters for exhibition, retrieving the physical stock at the end of the theatrical run. ${ }^{80}$ That course of action matches the first set of facts hypothesized above. Alternatively, motion-picture studios also have the option of distributing tangible copies of their films - as they have done since the advent of the videotape era. ${ }^{81}$ That conduct from the 1980 s to the present matches the second scenario.

Software publishers likewise enjoy the same rights. They can engage solely in rental or lease of physical media, mandating return of the

77. See 17 U.S.C. $§ 109$ (1994). Note that the statute itself does not actually require a "sale" for the section's protections to be triggered; instead it applies to all "owners" of lawfully made copies.

78. See Nimmer, Brains, supra note 53, at 22.

79. An exception to the copyright owner's exclusive reproduction right of course is coterminous with the rights secured to users to actually exploit the coinputer program, guaranteed to thein under 17 U.S.C. § 117.

80. In the later era of television syndication, film proprietors adopted the practice of "bicycling" film prints from one television station to another, again to preserve strict control over the physical stock. See National Broad. Co. v. Sonneborn, 870 F.2d 40, 51 (2d Cir. 1989).

81. See 2 Nimmer ON CoPYRIGHT, supra note $13, \S 8 \mathrm{~B} .01[\mathrm{~B}]$. 
subject tangible items at the end of the term. Or they can incorporate their software onto physical items that they then release from their control, setting them mto the stream of commerce. In the latter instance, the end user, while admittedly a licensee of the copyright, is not a licensee of the diskette or CD-ROM in her possession. Instead, she is the owner of those physical media containing licensed works. As such, she is clothed with full rights under the first-sale doctrine. No innovation in software distribution so far has forced reevaluation of the traditional paradigm.

Which circumstance actually obtained in Microsoft $v$. Harmony, the exemplar of the "licensing" paradigm? Sadly, the opinion fails to clarify the matter, and that inability to distinguish between differing paradigms is only too typical. ${ }^{82}$ Nonetheless, lack of clarity does not create a new "licensing" paradigm. Instead, if there were a bona fide lease of the physical goods, then one legal regime pertained; if Microsoft actually sold or otherwise permanently disposed of those physical goods, retaining full copyright ownership in itself, then another legal regime governed. Current copyright law does not recognize any regime of "licensing" 83 that stands intermediate between those two possibilities. ${ }^{84}$

82. Other examples are Microsofi Corp. v. Gray Computer, 910 F. Supp. 1077, 1084 (D. Md. 1995) and Triad Systems. Corp. v. Southeastern Express Co., 64 F.3d 1330, 1333 (9th Cir. 1995). See generally 2 NIMMER ON COPYRIGHT, supra note 13, § 8.12[B][1]. See also Nimmer, Brains, supra note 53, at 21-25 (discussing MAI v. Peak, 991 F.2d 511).

83. In Quality King Distributors, Inc. v. L'Anza Research International, Inc., 118 S. Ct. 1125 (1998), the Supreme Court distinguishes between the "owner' of a lawfully made copy" and "any nonowner such as a bailee, a licensee, a consignee, or one whose possession of the copy was unlawful." 118 S. Ct. at 1131. Standing by itself, that dictum cannot illuminate who, in the Court's mind, deserves the status of "licensee," although its juxtaposition with "a bailee [and] a consignee" hints that the Court views "a licensee" in this context as one who has not obtained ownership of the physical product, corresponding to the category posited above of "license of tangible medium." We thus must revert to the potential constructions of that term set forth in the text.

84. It is instructive to undertake some archaeological excavation into the myth that a separate "licensing" paradigm exists. One student commentator maintains that "if the software is only licensed, then the software developer may prevent the user from transferring ownership in a copy to a third party." Ira V. Heffen, Note, Copyleft: Licensing Collaborative Works in the Digital Age, 49 STAN. L. REv. 1487, 1499 (1997). As support, the Note cites the current case of Microsoft v. Harmony and traces its genealogy back to a handbook published by the Practicing Law Institute. See id. at 1494 n.37 (citing William H. Neukom \& Robert W. Gomulkiewicz, Licensing Rights to Computer Software, in Technology Licensing and Limigation 1993, at 778 (PLI Patents, Copyrights, Tradcinarks \& Literary Property Course Handbook Series No. G4-3897, 1993), available in WESTLAW, 354 PLI/Pat 775). The authors of that PLI handbook serve as Senior Vice President for Law and Corporate Affairs and Senior Corporate Attorney, respectively, with Microsoft Corporation. They explain "that software publishers license rather than sell software in order to negate the doctrine of first sale ...." Id. One must congratulate their employer on realizing, in Microsoft v. Harmony, its goal-conceded with admirable candor-of voiding copyright's first-sale doctrine. Nonetheless, for the reasons set forth in the text, the statute itself does not permit that result, to the extent that the underlying essence of the transaction results in a user obtaining ownership of the physical product containing the copyrightable expression. 
Nonetheless, an innovation might be said to be occurring through Internet distribution. Are the old barriers breaking down such that U.C.C. Article 2B must come to the rescue of a tottering copyright system? We answer that question, too, in the negative. As the foregoing example of Pandion reveals, ${ }^{85}$ purchases over the Internet do not suffer from a fatal lack of privity between software owner and end user which requires legal redress. Instead, copyright law itself governs the usages to which Pandion may put the product that he purchased over the Internet.

Indeed, it is possible to go further here. Someone like Pandion who purchases SuperSmart 321 as embodied in CD-ROM form has unambiguously acquired the right to pass the CD-ROM on to a friend. Does a parity of reasoning indicate that Pandion himself likewise has the right to sell his computer when he wishes to upgrade his whole system, even if the hard drive thereby transferred contains a copy of SuperSmart 321 that he purchased over the Internet?

Now the pedal comes down to the metal: Can Pandion keep his computer, deferring upgrades to a later day, but nonetheless pass along solely SuperSmart 321 (by transferring the files to a friend and deleting them froin his own hard drive, let us say)? There are two possible answers to this question:

Yes. Under this rationale, Pandion can take advantage of a "digital first-sale defense." ${ }^{86}$ Pandion, by this logic, is as much an owner of the "copy" purchased over the Internet as he would be of the CD-ROM. Granted, the copy in this instance cannot be as conveniently hefted and hoisted aloft, but the mere fact of its dispersion over manifold sectors of the hard drive does not detract from its status as a material object in which the subject software is fixed and from which it can be retrieved. ${ }^{87}$

No. An alternative view is that Internet distribution is different. No tangible copy has been released, because there is no discrete "material object" of the type invoked above that contains SuperSmart 321. The ever-shifting sectors and buffers where the work flits and dances fail to qualify as either "material" or an "object" under the statutory language.

The latter view - that Internet distribution is different because it does not result in a "copy"-must be rejected as implausible. For were it correct that the recipient of an Internet imstantiation does not obtain a "copy," Pandion would be able to distribute that instantiation freely

85. See supra Section II.A.

86. Nimmer, Brains, supra note 53, at 9, 33.

87. See 17 U.S.C. $\$ 101$ (1994) (defining “copy"); MAI Systems Corp. v. Peak Computer, Inc., 991 F.2d 511, 518 (9th Cir. 1993) (stating that "loading of copyrighted software into RAM creates a 'copy' of that software" under the copyright laws). 
over the Internet to thousands of remote recipients without infringing the copyright in SuperSmart $321 .^{88}$ Such a construction would be disastrous for copyright owners, and should not be viewed as implementing Congress's intent.

It is not necessary, however, to resolve whether Internet distribution results in a "copy" to test the adaptability of extant copyright law to new technologies. Under the "yes" view, Pandion may dispose of his volatile "copy" under the first-sale doctrine; under the "no" view, he cannot. Under the former view, Internet sales of software are assimilated to current methods of film exploitation via videocassettes, laser discs, DVD, and the rest (that is, a first sale arises), whereas under the latter view, such sales are assimilated to motion-picture distribution in the prevideotape era (that is, there was no first sale). In either event, no new paradigm is required. ${ }^{89}$

In sum, the new paradigm of "licensing" instead of sales, on the one hand, and lending, on the other hand, collapses. For that reason, no new conceptual breakthrough via U.C.C. Article $2 B$ is required.

\section{III}

\section{The Limits on Contract via the Preemptive Force of Copyright}

Our discussion in Part I demonstrates that state contract law acts as a necessary complement to the Copyright Act by delineating the basic mechanics of contract formation, performance, and interpretation. Those salutary goals can find further expression in Article $2 \mathrm{~B}$. The analysis in Part II demonstrates that state contract law is not needed to protect the copyright interests of copyright proprietors. Those interests are safeguarded by the Copyright Act itself. What remains to be discussed are the ways in which state contract law can improperly meddle with the copyright laws by altering the copyright laws in favor of proprietors at the expense of users. The phenomenon of attempted contractual displacement of copyright, and the limits of contract in that regard, arises in the doctrinal context of preemption.

\section{A. General Preemption Notions}

Copyright law and contract law not only clash overtly but may clash covertly to the extent that they pursue different implicit purposes and objectives. When conflicts occur, preemption principles force state contract law to yield. The source of copyright's preemptive power is the Umited States Constitution. To the extent that any state law "stands as an obstacle to the accomplishment and execution of the full purposes and

88. See 17 U.S.C. $§ \$ 106(1),(3)$ (1994) (limiting copyright owner's rights to reproduction and distribution of "copies").

89. See Nimmer, Brains, supra note 53, at 11 . 
objectives of Congress," of Congress reign supreme..$^{11}$

Some cases describe preemption as the upshot of a clash between state and federal law in which state law is vanquished..$^{2}$ Other cases have enunciated even stricter principles according to which federal law does not tolerate parallel state regimes. ${ }^{93}$ As the Supreme Court put it in its most recent pronouncement on the subject of parallel regimes of federal and state intellectual property protection, "The offer of federal protection from competitive exploitation of intellectual property would be rendered meamingless in a world where substantially similar state law protections were readily available."94

On the other hand, im one case predating the adoption of the current Act, the Supreme Court allowed greater tolerance for state schemes covering the same subject matter as copyright. In particular, Goldstein v. California ${ }^{95}$ held that the states retain concurrent power to afford copyright protection to the works of authors as long as such protection does not conflict with federal law. Nonetheless, state laws enacted pursuant to such concurrent power can, of course, be subject to preemption by federal statute.

When enacting section 301 of the current Act, Congress took precisely that action of preempting concurrent state law in the copyright domaim. Unlike the parallel federal and state tracks that previously applied to the copyright realm, section 301 federalizes much of the domain of protection for copyrightable expression. ${ }^{96}$ By reason of that explicit federal preemption, states' concurrent copyright powers lack almost all practical significance. ${ }^{97}$

90. Hines v. Davidowitz, 312 U.S. 52, 67 (1941).

91. Constitutional preemption of a competing state law regime was established in the first copyright case to go before the Supreme Court. See Wheaton v. Peters, 33 U.S. (8 Pet.) 591 (1834) (holding federal copyright law preempts state common law protection for published works).

92. See Kewanee Oil Co. v. Bicron Corp., 416 U.S. 470, 480 (1974) ("[I]f the scheme of protection developed by [a state] ... 'clashes with the objectives of the federal ... laws' then the state law must fall." (citation omitted)).

93. See, e.g., Compco Corp. v. Day-Brite Lighting, Inc., 376 U.S. 234, 237 (1964) ("[W]hen an article is unprotected by a patent or a copyright, state law may not forbid others to copy that article. To forbid copying would interfere with the federal policy, found in Art. I, $\S 8$, cl. 8 , of the Constitution and in the implementing federal statutes, of allowing free access to copy whatever the federal patent and copyright laws leave in the public domain.")

94. Bonito Boats, Inc. v. Thunder Craft Boats, Inc., 489 U.S. 141, 151 (1989).

95. 412 U.S. 546,570 (1973).

96. For certain residual inatters that the states may still regulate, such as unfixed works and phonorecords pre-dating February 15, 1972, see 1 NIMMER ON COPYRIGHT, supra note 13, § 2.02 .

97. Goldstein held that state law is not preempted if "Congress has drawn no balance; rather, it has left the area unattended ..." 412 U.S. at 570. As a practical matter it may often be hard, if not impossible, to distinguish benign from conscious neglect, that is, to know if Congress has "left the area unattended," or whether Congress affirmatively decided that federal protection is not available. 


\section{B. A Case Study in the Contract/Copyright Clash: ProCD v. Zeidenberg}

\section{A Twist on Feist}

In ProCD, Inc. v. Zeidenberg ${ }^{98}$ plaintiff spent millions of dollars to produce a massive "telephone book" of nationwide scope. Because the "book" contained almost one hundred million listings, plaintiff released it on CD-ROM with copyrighted search software designed to navigate through the mass of information. The CD-ROM was placed in a box that stated that the software came with restrictions listed in an enclosed license. The license was encoded on the CD-ROM discs, printed in the manual, and appeared on a user's screen every time the software ran. It expressly provided that the end user "will not make the [search] Software or the [telephone] Listings in whole or in part available to any other user in any networked or time-shared environment, or transfer the Listings $\mathrm{m}$ whole or in part to any computer other than the computer used to access the Listings." 99

When the matter under discussion combines listing from the white pages of the telephone book and allegations of copyright infringement, the Supreme Court's landmark holding in Feist Publications, Inc. v. Rural Telephone Service Co. springs immediately to mind. ${ }^{100}$ If that unanimous decision made anything clear, it is that not even a massive expenditure of funds to compile phone listings can render them copyrightable. Instead, they repose in the public domain - both as a matter of statutory construction and of constitutional necessity. Relying on Feist, defendants in ProCD copied all the listings off the plaintiff's CDROMs, composed their own software to access the names and addresses, and went into business in competition with plaintiff by making all the listings available for search on an Internet web page.

The plaintiff responded by bringing suit. Barred by Feist from bringing a copyright claim against the copying of telephone listings, plamtiffs sought redress against defendants' constitutionally privileged copying by alleging breach of contract and misappropriation.

\section{Issues State and Federal}

On the latter cause of action, the district court concluded that "because plaintiff's misappropriation claim is not qualitatively different from a copyright infringement claim, the underlying rights plaintiff seeks to vindicate are equivalent to federal rights and are preempted by the Copyright Act."101 In reference to the contract issue, the district

98. 908 F. Supp. 640 (W.D. Wis.), rev'd, 86 F.3d 1447 (7th Cir. 1996).

99. ProCD, 908 F. Supp. at 645.

100. 499 U.S. 340 (1991).

101. ProCD, 908 F. Supp. at 661. 
court noted that most commentators disfavor rights asserted under shrinkwrap licenses, given users' inability to bargain over precise terms. More fundamentally, those licenses "pose important questions about the extent to which individual contract provisions can supplement or expand federal copyright protection." 102 The district court accordingly concluded that section 301 preempted the contract claim. As Chief Judge Crabb held, any other ruling would "alter the 'delicate balance' of copyright law" and, inore particularly, constitute an impermissible end-run around Feist. ${ }^{103}$

This solicitude for "delicate balance" is not an aberration. As the Supreme Court itself has noted,

[I] $t$ is Congress that has been assigned the task of defining the scope of the limited monopoly that should be granted to authors or to inventors.... [T] his task involves a difficult balance between the interests of authors and inventors in the control and exploitation of their writings and discoveries on the one hand, and society's competing imterest in the free flow of ideas, information, and commerce on the other hand .... ${ }^{104}$

This ventilation of the contract issue in the context of copyright poses two analytically separate issues. ${ }^{105}$ The first question is whether, as a matter of contract law, the shrinkwrap license unilaterally inposed by the manufacturer constitutes a binding agreement. That first question implicates construction of state law, nanely, the Uniform Commercial Code as implemented into Wisconsin law. Assuming an affirmative answer, the second question is whether that contract can govern in the copyright context. This second question arises under federal law, as a matter of preenption via the statute or the Constitution.

The district court resolved both matters adversely to ProCD, Inc. In reversing, the Seventh Circuit reached the contrary conclusion on both scores. ${ }^{106}$ To isolate the preemption issue posed by this case, ${ }^{107}$ we assume for current purposes that the subject contract is either enforceable

102. Id. at 650 .

103. Id. at 658 .

104. Sony Corp. v. Universal City Studios, Inc., 464 U.S. 417, 429 (1984); accord Twentieth Century Music Corp. v. Aiken, 422 U.S. 151, 156 (1975) ("The limited scope of the copyright holder's statutory nonopoly, like the limited copyright duration required by the Constitution, reflect a balance of competing claims upon the public interest." (citation omitted)).

105. For a valuable untangling of the two strands implicated here, see Maureen A. O'Rourke, Copyright Preemption After the ProCD Case: A Market-Based Approach, 12 BeRKeley TeCH. L.J. 53 (1997).

106. There is no need for the two issues to march in lockstep. Theoretically, one could determine that plaintiff has the better argument under state contract law as implemented through the U.C.C., but that defendant is correct in urging that the Copyright Act preempts the U.C.C. construction. See id.

107. See infra Part II.C. 
under the U.C.C. as currently drafted ${ }^{108}$ or that it would be enforceable under Article 2B. The question thereby framed is whether ProCD, Inc.'s contract restrictions on copying can stand consistent with federal norms. This preemption inquiry itself occupies two levels, statutory and constitutional.

\section{A Step Back into History}

Before proceeding to a full-scale exploration of the issue posed in ProCD of whether copyright law preempts application of the U.C.C. in this arena, it is worthwhile to ponder precursor scenarios. ProCD, Inc. was far from the first copyright owner to attempt to magnify its rights via contract. Indeed, it is almost commonplace in the history of copyright jurisprudence that when new technology establishes products or media considered incapable of being protected, copyright owners seek self-help through the unilateral declaration of expanded rights via purported contractual limitations.

Consider the diminution of sheet music sales and the advent of sound recordings played over the radio. ${ }^{109}$ Given the lack of a public performance right in those sound recordings as a matter of law, ${ }^{10} \mathrm{RCA}$ decided to cure the law's lacunae by affixing the following language to its products:

Only For Non-Comunercial Use on Phonographs in Homes.

Mfr. \& Original Purchaser Have Agreed This Record Shall Not

Be Resold Or Used For Any Other Purpose. See Detailed Notice

on Envelope. ${ }^{111}$

When the purchaser"12 of the records ignored that "shrinkwrap" contract-thus anticipating Zeidenberg's conduct by a half-century-by

108. One commentator's exhaustive analysis reaches this conclusion. See O'Rourke, supra note 105. In any event, even if the current U.C.C. inclined in the other direction, the U.C.C., as amendcd by Article $2 \mathrm{~B}$, would unambiguously mandate this result, thus necessitating the inquiry into prccmption vel non. See infra Section IV.B.

109. "Until the phonographic record made possible the preservation and reproduction of sound, all audible renditions were of necessity fugitive .... Of late, however, the power to reproduce the exact quahity and sequence of sounds has become possible, and the right to do so, exceedingly valuable .... Hence this action." RCA Mfg. Co. v. Whiteman, 114 F.2d 86, 88 (2d Cir. 1940).

110. Sound recordings enjoycd no federal protection until February 15, 1972. Even since that time, federal copyright for sound recordings has included no public performance right in one narrow particular. See 2 Nimmer on COPYRIGHT, supra note 13, $\$ 8.21$ (discussing Digital Performance Right in Sound Recordings Act of 1995).

111. $R C A, 114$ F.2d at 87.

112. Of course, precedents are rarely pristine. In $R C A$, it actually was not the direct purchaser from RCA who subsequently played the records over the air; instead, there was a middleman. But the facts in this case were such that "[ilt may be assumed that [the defendant] is charged with notice of the legends on the records, and with the contract of [the middleman], and that it broadcasts them on its radio system in disregard of both." Id. at 87. Accordingly, the facts of this case do not correspond to someone who just happened to find the subject product on the street. See ProCD, 86 F.3d at 1454 
broadcasting them for profit over the air, the manufacturer responded by filing suit. No less an authority than Learned Hand summarily rebuffed the claim. ${ }^{113}$

One could reach back even further and likewise find the same rejection of copyright proprietors' attempts to tilt the "delicate balance" in their favor. In 1908 the Supreme Court enunciated the "first sale"114 doctrine when it refused to enforce a book publisher's protoshrinkwrap license barring any retail sale of the books there at issue for a price less than $\$ 1.00 .{ }^{115}$ Even earlier than that, a lower court had likewise refused to enforce use restrictions placed on the inside cover of a book. ${ }^{116}$

With that history in mind, ProCD, Inc. v. Zeidenberg is not novel. Earlier actors throughout the twentieth century had similarly attempted to magnify their rights through use of contract. The novelty of ProCD thus lies not in the use of that device, but instead in the fact that the Seventh Circuit was the first court that did not dismiss as ineffectual a copyright owner's purported recalibration of the "delicate balance."

\section{Preemption Analysis of $\mathrm{ProCD}^{117}$}

\section{Section 301}

As already noted, the district court concluded that a ruling in favor of ProCD, Inc., would subvert Feist; indeed, there can be little doubt that plaintiff crafted its shrinkwrap with that precise goal in mind. The court's invocation of a subversive assault on a recent on-point Supreme Court precedent should have brought to mind general conflict

(acknowledging that subject contract would have no power over that individual in the street who utterly lacked privity).

113. See 114 F.2d. at 88 ("[T]he records themselves could not be clogged with a servitude.").

114. See 17 U.S.C. § 109 (1994).

115. See Bobbs-Mertill Co v. Straus, 210 U.S. 339, 350 (1908). The continued vitality of the Bobbs-Merrill case emerges tacitly from its acknowledgment in the Supreme Court's recent unanimous decisions concerning the importation of gray-market goods. See Quality King Distribs. Inc. v. L'Anza Research Int'l, Inc., $118 \mathrm{~S}$. Ct. 1125 (1998). Note that RCA v. Whiteman likewise cites back to Bobbs-Merrill. See 114 F.2d at 88. It should be noted that in Bobbs-Merrill, the Supreme Court stated, "In our view the copyright statutes, while protecting the owner of the copyright in his right to multiply and sell his production, do not create the right to impose, by notice, such as is disclosed in this case, a limitation at which the book shall be sold at retail by future purchasers, with whom there is no privity of contract." 210 U.S. at 350 (emphasis added). To the extent that such absence of privity is viewed as necessary to the holding of Bobbs-Merrill, then U.C.C. Article 2B's creation of "a direct contractual relationship" between copyright owner and end user serves as a subterfuge to undermine the first-sale doctrine, notwithstanding that Congress has labeled it "a basic tenet of our intellectual property law.” H.R. Rep, No. 98-781 at 23 (1984); see supra note 84.

116. Authors \& Newspapers Ass'n v. O'Gorman Co., 147 F. 616 (D.R.I. 1906).

117. The discussion in this Section derives from the criticism of the Seventh Circuit's ProCD opinion in Release 44 to NMMER ON COPYRIGHT, supra note 13. (c) 1998 by Matthew Bender \& Co., Inc. Reprinted with permission. 
pre-emption under the Supremacy Clause. ${ }^{118}$ Yet although its reference to copyright's "delicate balance" adverts to general preemption under the Supremacy Clause, the district court ultimately failed to contemplate preemption on that non-statutory basis. Instead, Chief Judge Crabb grounded her analysis entirely on the narrower statutory grounds for preemption under section 301.

Section 301 preempts state-created legal or equitable rights, whether based upon common law or statute, under the following conditions: (1) the state law creates "legal or equitable rights that are equivalent to any of the exclusive rights within the general scope of copyright as specified by Section 106" and, (2) such rights under such state law may be claimed in "works of authorship that are fixed in a tangible medium of expression and come within the subject matter of copyright ... whether created before or after [January 1, 1978] and whether published or unpublished...."119 Thus, two elements must coalesce in order to effectuate section 301 preemption, the first relating to the nature of the rights granted under state law, the second to the nature of the work in which such rights may be claimed.

The first element was the one at issue in this case. ${ }^{120}$ It is triggered if the state-created act is infringed merely by engaging in one of the exclusive rights of authors under the Copyright Act-such as the right to reproduce. If, however, in addition to, or instead of, amounting to one of the exclusive rights of authors under the Copyright Act, a qualitatively different element is required, then the right does not lie "within the general scope of copyright," and there is no preemption. This is known as the "extra element" test. ${ }^{121}$

Reported cases confronting alleged copyright preemption under section 301 of contract causes of action have almost uniformly rebuffed the preemption claim. That doctrinal result is as it should be: the vast majority of copyright contracts easily withstand muster under section 301 because the breach alleged amounts to more than reproduction, distribution, etc., of a copyrighted work. In other words, the typical contract case satisfies the "extra element" test. The rub arises in ProCD in that plaintiff there drafted a contract that was exceptional when contrasted with that vast majority.

The district court in ProCD concluded that efforts to enforce the contract there at issue were precisely congruent with a copyright claim

118. See supra Section III.A.

119. 17 U.S.C. $\$ 301$ (1994).

120. The other requisite ingredient for preemption under section 301 , as just noted, is that the regulated matter must fall "within the subject matter of copyright." 17 U.S.C. $\$ 301$ (a) (1994). On that latter point, the Seventh Circuit agreed with the district court that the telephone histings at issue fell within that subject matter. See ProCD, Inc. v. Zeidenbcrg, 86 F.3d 1447, 1453 (7th Cir. 1996).

121. See, e.g., Trandes Corp. v. Guy F. Atkinson Co., 996 F.2d 655, 659 (4th Cir. 1993). 
(and therefore, implicitly, failed the "extra element" test). But in an inexplicable move that then undermined the basis for its own ruling, the court viewed itself as disagreeing with a trinity of appellate decisions that had found particular contract claims not preempted: the Eighth Circuit's ruling in National Car Rental System, Inc. v. Computer Associates International, Inc. ${ }^{122}$ the Fifth Circuit's ruling in Taquino $v$. Teledyne Monarch Rubber, ${ }^{123}$ and the Fourth Circuit's ruling in Acorn Structures, Inc. v. Swantz. ${ }^{124}$ The district court in ProCD stated, "To the extent that National Car Rental, Taquino,... and Acorn support the proposition that a copyright infringenent claim is not equivalent to a contract claim inerely because the contract claim requires a plaintiff to show the additional element of breach, I disagree respectfully with their conclusions." 125

Couched in those terms, an affirmance would seem to proclaim "circuit conflict," thus inviting certiorari. In fact, however, the holding of preemption under these circumstances was not as unprecedented as Chief Judge Crabb allowed. To appreciate why, we must broaden our sights from causes of action alleging pure breach of contract to those that arise in a contracts-plus situation.

When the current Act was being deliberated, the House Committee Report stated that the tort of "interference with contract relations" is "merely the equivalent of copyright protection, [and therefore] would be preempted."126 On that basis, courts have held that particular contract-based tort preempted under section 301 of the Copyright Act. ${ }^{127}$ This result would appear doctrinally correct. ${ }^{128}$ Moreover, it has been extended as well to closely allied torts, such as interference

122. 991 F.2d 426, 433 (8th Cir. 1993).

123. 893 F.2d 1488, 1501 (5th Cir. 1990).

124. 846 F.2d 923, 926 (4th Cir. 1988).

125. 908 F. Supp. 640, 658 (W.D. Wis.), rev'd, 86 F.3d 1447 (7th Cir. 1996).

126. H.R. Rep. No. 94-1476 at 132 (1976), reprinted in 1976 U.S.C.C.A.N. 5659, 5748. Note that this language confronted statutory language that was later amended. See 1 NIMMER ON COPYRIGHT, supra note $13, \S 1.01[\mathrm{~B}][1][\mathrm{a}]$.

127. See Harper \& Row, Publishers, Inc. v. Nation Enters., 501 F. Supp. 848 (S.D.N.Y. 1980), aff'd, 723 F.2d 195 (2d Cir. 1983), rev'd on other grounds, 471 U.S. 539 (1985); Kamakazi Music Corp. v. Robbins Music Corp., 522 F. Supp. 125 (S.D.N.Y. 1981), aff d, 684 F.2d 228 (2d Cir. 1982).

128. Insofar as unauthorized reproduction, distribution, performance, or display causes the plaintiff to lose the benefits that would flow from an actual or prospective contract whereby plaintiff would authorize any such acts, the rights created by the tort of contract interference do not appear to differ qualitatively from rights under copyright; copyright also contemplates loss of actual or prospective contract benefits by reason of such unauthorized acts. Preemption in this context would, then, appear to be justified. The fact that the tort, unlike copyright infringement, requires awareness of the conflicting contract and an intentional interference with it merely means that the state-created right is narrower than its copyright counterpart, not that it is qualitatively different so as to preclude preeinption. See 1 NIMMER ON COPYRIGHT, supra note 13, § 1.01[B][1][a]. 
with prospective economic advantage for foiling consummation of a copyright contract under negotiation. ${ }^{129}$

With this larger perspective in mind, the rectitude of Chief Judge Crabb's conclusion can be appreciated. When two parties to a negotiated contract-even one for exploitation of copyrighted goods-dispute its terms and application, the allegation of breach is typically not preempted. But just as the tort of interference with contractual relations attempts to regulate the same subject matter as does copyright law and is therefore preempted, when a breach of contract cause of actionparticularly one that does not result from the bargained-for agreement of both parties to its putative execution-is used as a subterfuge to control nothing other than the reproduction, adaptation, public distribution, etc., of works within the subject matter of copyright, then it too should be deemed preempted.

The facts of the last scenario underlay those in ProCD. The plaintiff was seeking to control the exclusive rights granted by copyright law every bit as much as in a preempted cause of action denominated "interference with contract relations." It sought, in short, to bar further public distribution of materials, a right that belongs to copyright owners under the statute. ${ }^{130}$ But it sought to do so with respect to a subject matter-listings in the white pages of a telephone book-that a unanimous Supreme Court had ruled to be in the public domain.

Because the district court did not cite those considerations, and instead proclaimed itself at odds with previous circuit precedent on the subject, it set itself up for reversal. The Seventh Circuit, as it were, accepted the invitation: "But are rights created by contract "equivalent to any of the exclusive rights within the general scope of copyright'? Three courts of appeals have answered 'no.' The district court disagreed with these decisions, but we think them sound."131

The first comment about the Seventh Circuit's adherence to the district court's supposed disagreement with the three previous cases is that each examined contracts in a context apart from shrinkwrap licenses. By contrast, the previous pronouncement by a circuit court on that latter subject upheld copyright preemption. ${ }^{132}$ Accordingly, strict

129. See PMC, Inc. v. Saban Entertainment, Inc., 52 Cal. Rptr. 2d 877, 885 (Cal. Ct. App. 1996) (dealing with rival bids to enter copyright contract to manufacture "Power Rangers" products), discussed in 1 NIMMER ON COPYRIGHT, supra note $13, \S 1.01[\mathrm{~B}][1][\mathrm{a}]$.

130. See 17 U.S.C. \& 106(3) (1994).

131. ProCD, 86 F.3d at 1454 (citations omitted).

132. See Vault Corp. v. Quaid Software Ltd., 847 F.2d 255 (5th Cir. 1988) (finding contract clause barring decompilation or disassembly to be unenforceable). The Fifth Circuit affirmed the lower court opinion on this point, as it did again in Taquino v. Teledyne Monarch Rubber, 893 F.2d 1488 (5th Cir. 1990), discussed infra in text accompanying note 139. 
adherence to precedent, without even examining the issues afresh, supports, rather than undermines, the district court's preemption ruling.

Moreover, examination of each of the three cited circuit court decisions reveals that it is, in fact, unnecessary to disagree with them in order to preserve the scope of section 301 and concur in the district court's preemption holding. Rather than viewing those cases as being governed by a wholly different rule than the district court followed, each of their holdings can best be understood as turning on the specific facts presented. None supports the Seventh Circuit's broad conclusion that "whether a particular license is generous or restrictive, a simple twoparty contract is not 'equivalent to any of the exclusive rights within the general scope of copyright' and therefore may be enforced."133

First, Judge Easterbrook's reversal of the district court's holding in ProCD cites National Car Rental for the sweeping proposition that "rights created by contract" are not "equivalent to any of the exclusive rights within the general scope of copyright." 134 Although that latter case did hold that the specific contract there at issue was not preempted, it did not extend its holding to contracts in general. In fact, explicitly relying on the "extra element rule," National Car Rental held that "the contractual restriction" that prohibited "processing of data for third parties" was qualitatively different from a contract that could be "breached "by the inere act of reproduction, performance, distribution or display." 135 Because "[n]one of the exclusive copyright rights grant [the copyright owner] that right of their own force," and because "[a]bsent the parties" agreement, this restriction would not exist," the court concluded that the "contractual restriction on use of the programs constitutes an extra element that makes this cause of action qualitatively different from one for copyright."136 Invoking the extra element rule, National Car Rental approvingly cited the Ninth Circuit's Kalitta ruling, "Copyright preemption is both explicit and broad: [It] prohibits statelaw protection for any right equivalent to those in the Copyright Act." 137 Turning to the copying of the software at issue in ProCD, it was (in the words of Kalitta) "in and of itself,' [an act which] 'would infringe one of the exclusive rights listed in $\S 106$. ."138 Under the Kalitta standard approved by National Car Rental, the license at issue in ProCD should therefore be held preempted, thus bolstering rather than undermining the district court's conclusion.

133. ProCD, 86 F.3d at 1455 (citation omitted).

134. Id. at 1454.

135. 991 F.2d at 433 (citation omitted).

136. Id.

137. G.S. Rasinussen \& Assocs. v. Kalitta Flying Serv., 958 F.2d 896, 904 (9th Cir. 1992).

138. Id. 
In Taquino, the contract at issue "forbade [the defendant] from representing a competing company prior to termination," a restriction not equivalent to copyright:

The right to claim this breach of contract is not preempted by the copyright laws. 17 U.S.C. $\S 301$ only preempts rights equivalent to the exclusive rights within the general scope of copyright law. A right is equivalent if the mere act of reproduction, distribution, or display infringes it. This action for breach of contract involves an element in addition to mere reproduction, distribution, or display .... ${ }^{139}$

Similarly, the contractual restriction in Acorn did not implicate the rights granted by the Copyright Act:

Implicit in the contract between Acorn and Swantz was an agreement that while Swantz did not have to use Acorn's plans, if he did use Acorn's plans then he was obligated either to purchase the plans from Acorn or to purchase his building materials from Acorn .... This implicit provision of the contract ... does not arise out of the subject matter of copyright and is therefore a separate and distinct cause of action. ${ }^{140}$

The fact-specific holdings of these cases-that contracts that did not merely forbid reproduction, distribution, or display are not preempted-follow the same rule as National Car Rental. Accordingly, parallel logic dictates that Taquino and Acorn in no way undermine the district court's ruling.

Having run through the triad of cases that underlay both the district and circuit courts' analysis in ProCD, it appears that the rule safeguarding contract causes of action against copyright preemption is less than categorical. Although the vast majority of contract claims will presumably survive scrutiny - as did each of the contract claims confronted in that trio-preemption should continue to strike down claims that, though denominated "contract," nonetheless complain directly about the reproduction right. It is precisely into that paradigm that the facts of ProCD fall.

\section{Giving Supremacy to the Supremes}

We have already seen that rights premised under state law cannot stand as "an obstacle to the full purposes and objectives of Congress." "141 As construed by a unanimous Supreme Court in Feist, Congress did not (and, indeed, constitutionally could not) extend copyright protection to alphabetical telephone listings. The shrinkwrap

139. $893 \mathrm{~F} .2 \mathrm{~d}$ at 1501 (citations omitted) (quoting opinion of district court).

140. $846 \mathrm{~F} .2 \mathrm{~d}$ at 926 .

141. Hines v. Davidowitz, 312 U.S. 52, 67 (1941). See supra notes $90-91$ and accompanying text. 
license at issue in ProCD undid the right of the public that Feist conferred-the ability to copy telephone listings without liability. ${ }^{142}$ As such, there would seem to be a direct conflict between that which federal law permits and that which state law forbids. ${ }^{143}$

It is remarkable, then, that the Seventh Circuit reversed. Judge Easterbrook's opinion, after determining shrinkwrap licenses to be binding under the Unform Commercial Code, ${ }^{144}$ concluded that the district court erred in its construction of section 301.145 The Seventh Circuit did not consider constitutional preemption apart from section 301 , notwithstanding that, as discussed above, non-301 preemption occupies its own capacious niche in copyright jurisprudence. ${ }^{146}$ Combined with its facile reading of precedent under section $301,,^{147}$ its failure even to consider the broader constitutional issues dooms the Seventh Circuit's preemption analysis.

The court attempted to highlight the error of the district court's approach through a reductio ad absurdum

A customer visits a video store and rents a copy of Night of the Lepus. The customer's contract with the store limits use of the tape to home viewing and requires its return in two days. May the customer keep the tape, on the ground that $\S 301$ (a) makes the promise unenforceable? ${ }^{148}$

142. In individual cases, a contract to refrain from doing what copyright law permits may be eminently defensible. As developed below, the mischief in the blanket contract in ProCD is that plaintiff wanted to have its cake and eat it too-to exploit telephone histings via mass market distribution, and to bar the whole world from copying its listing. Had plaintiff been content to maintain its database of listings as a trade secret, for example, then its contracts would have likely withstood a preemption challenge. See infra Section III.D.1.

143. One can avoid the conflict by postulating that Congress would have protected phone listings, but was constrained by its constitutional limits not to do so. On that theory, contractual law merely supplemented Congress' designs, using the states' residual power to extend the vector that Congress drew to the limits of its own ability. This avenue of escape, however, was foreclosed by the Seventh Circuit, when it held that the one aspect of the district court's ruling that was "plainly right" was its conclusion that ProCD's software and data "are 'within the subject matter of copyright' even if, after Feist, they are not sufficiently original to be copyrighted." ProCD, 86 F.3d at 1453 (quoting ProCD v. Zeidenberg, 908 F. Supp. 640, 665-67 (W.D. Wis. 1996)). In this regard, the subject matter at issue in ProCD differs at base from those works not fixed in any tangible medium of expression - such as oral sermons and jazz improvisations-over which state law can continue to afford protection. See supra note 96; see generally 1 NIMMER ON COPYRIGHT, supra note $13, \S 2.02$.

144. See supra Section III.B.1.

145. See ProCD, 86 F.3d at 1454.

146. See supra Section III.A. For an analysis of many cases arising in that posture, ranging from the Supreme Court's invalidation of an Oklahoma law banning re-transmission of out-of-state commercials for alcoholic beverages to a district court's invalidation of an ordinance ruling exclusive licenses of cable programming illegal on antitrust grounds (again, a copyright/contract cross-over) to blind bidding of films to public disclosure of standardized tests, see 1 NIMMER ON COPYRIGHT, supra note $13, \S 1.01[\mathrm{~B}][3][\mathrm{c}]$.

147. See supra Section III.C.1.

148. ProCD, 86 F.3d at 1454. 
The answer to that rhetorical question is as patent as it is incomplete. In this particular instance, the contract relating to copyrightable goods should be deemed enforceable, as it passes the "extra element" test and contravenes no federal policy. That solitary hypothetical at best demonstrates what is uncontroversial: not every contract relating to copyrightable goods is preempted. ${ }^{149}$ It does not demonstrate the far greater proposition at which it hints: No contract relating to copyrightable goods ever is preempted under section 301(a). Moreover, even when a contract passes muster under section 301, it is still necessary to evaluate whether it runs afoul of the more general preemption prerequisites mandated by the Constitution.

The court's hypothetical video store rental contract, albeit incomplete, still serves as a useful tool to further the inquiry. The contract at issue requiring the return of the physical copy at the end of the rental period meets the "extra element" test. Further, it contravenes no policy of the Copyright Act. To the contrary, it fosters the purposes underlying copyright law by encouraging the dissemination of copyrightable works in an orderly fashion. ${ }^{150}$ Likewise, the vast majority of contracts that one may posit with respect to copyrightable goods should prove easy to reconcile with the purposes underlying copyright. Whether the contract consists of imposing time limits on when films can be shown, specifying geographic limitations on where magazines can be distributed, or mandating quality controls on how sculptures can be displayed, each disserves no readily apparent doctrine of copyright law. Accordingly, these contracts are presumptively enforceable.

The contract at issue in ProCD, Inc. v. Zeidenberg differs from the foregoing examples in the one respect relevant to nonstatutory preemption: ${ }^{151}$ it contravenes one of the core policies of the Copyright Act by extending quasi-copyright protection to works that do not qualify as "original." 152 It further fails the test of encouraging the dissemination of copyrightable works in an orderly fashion in that it seeks to bar the dissemination of uncopyrightable materials. It is, in short, nothing other

149. See supra Section III.A. (Indeed, as previously noted, the vast majority pass muster).

150. Note that attempts to amend the Copyright Act to forbid video rentals have failed. See 2 NIMMER ON COPYRIGHT, supra note 13, § 8B.01[B] n.23.2. Had those amendments succeeded, then the posited video rental would contravene the purposes of the fictively amended Act; under those circumstances, the sample contract posited by the Seventh Circuit could well be deemcd unenforceable based on conflict preemption.

151. It also differs in that it fails the "extra element" test. See infra Section III.C.1.

152. In parallel fashion, one plaintiff attempted to protect her recipe, see Griggs v. South Carolina Elec. \& Gas Co., 467 S.E.2d 608, 609 (S.C. 1995), a subjcct matter that falls outside copyright protection, see 1 NIMMER ON COPYRIGHT, supra note 13, § 2.18[1]. Rather than labeling lier cause of action "breach of contract," she responded to unauthorized publication of a recipe by claiming "outrage"; her husband joined in for "loss of consortium." Those causes of actions likewise failed the "extra element" test. See Griggs, 467 S.E.2d at 609. 
than an attempt in effect to overrule by contract binding Supreme Court precedent. ${ }^{153}$

The Seventh Circuit conceded in ProCD, Inc. v. Zeidenberg that the structure of copyright law "prevents states from substituting their own regulatory systems for those of the national government." 154 On that basis, the Seventh Circuit refrained from "adopting a rule that anything with the label 'contract' is necessarily outside the preemption clause: the variations and possibilities are too numerous to foresee."155 One wonders what variation the court had in mind as embodying the substitution of a contractual scheme "for those of the national government" if not a factual scenario on all fours with a recent, unanimous Supreme Court opimion, but reaching the contrary result. ${ }^{156}$ Yet the opinion did not even mention Feist in its preemption analysis. ${ }^{157}$

To appreciate what is at issue here, it is useful to conjure up similar examples of contracts designed to evade the strictures of copyright law. Those variants shine a brighter light on the preemption inquiry than the Seventh Circuit's pedestrian example of a contractual obligation to return a single copy of a rented videotape. In each of the following exainples, the postulated conduct disturbs the "delicate balance" that the district court in ProCD was attempting to maintain. Adverting to the entire spectrum of preemption concerns (rather than simply to section 301) illustrates that each of these contracts must bow before the superior force of the federal enactment of copyright law.

Consider ${ }^{158}$ first a state law that validates all oral contracts solemnly adjured before a panel of three clergyinen. ${ }^{159}$ To the extent that that law were applied to a contract transferring copyright ownership, the

153. " $[\mathrm{H}]$ ad the state of Kansas adopted an exclusive-rights regime to protect databases after the Supreme Court's decision, and had Rural sued Feist for new appropriations from its white-page listings under that law, the Supreme Court would probably have struck the state law down for interfering with the federal copyright policy of promoting public access to knowledge." J.H. Reichman \& Pamela Samuelson, Intellectual Property Rights in Data?, 50 VAND. L. REv. 51, 144 (1997).

154. 86 F.3d at 1455 . The opinion even nods in the direction of conflict preemption by invoking "the possibility that some applications of the law of contract could interfere with the attainment of national objectives ...." Id.

155. Id.

156. Curiously, the opinion earlier conceded that one function of copyright law is to "prevent states from giving special protection to works of authorship that Congress has decided should be im the public domain ...." Id. at 1453 .

157. The court's previous reference to Feist consisted siniply of recounting that the subject telephone listings are not protected under copyright law. See id. at 1449. On the instant subject, the opinion blithely concluded that "general enforcement of shrinkwrap licenses of the kind before us does not create such interference [with the attainment of national objectives]." Id. at 1455.

158. In each instance, the lyypothetical state law could be conceived as implementing the Uniform Commercial Code within that particular jurisdiction. Alternatively, that law could be viewed as the will of the legislature separate from model enactment of the Code.

159. See supra note 36 . 
unanimous view of the cases is that it would be preempted under the Supremacy Clause, given the federal command that transfers of copyright ownership be executed in writing. ${ }^{160}$ That single hypothetical by itself proves that absolute freedom of contract under state law relating to copyrightable works is insupportable. ${ }^{161}$

Consider next a video store that does not simply limit customers to home viewing (as imagined by the Seventh Circuit's hypothetical), but goes further and stamps each videotape in its collection with the legend: MAY BE VIEWED BY NO MORE THAN THREE PEOPLE AT ONE SITTING. ${ }^{162}$ Even better, a studio that invariably stamped its product with that proviso in a shrinkwrap encasing all videotapes that it manufactured would closely mirror the actual facts of ProCD, Inc. $v$. Zeidenberg. For just as the plaintiff in that actual case sought to use a shrinkwrap to deny the public the right to use phone listings guaranteed by $F$ eist, so the fictive studio in this hypothetical case would use its own shrinkwrap to avoid Congress' limitation of the performance rights in videotapes to public performances, defined as occurring only when " a substantial number of persons" is gathered. ${ }^{163}$ The subject proviso, even if deeined operative as a matter of state contract law, should be deemed preeunpted based on its conflict with the federal scheme. ${ }^{164}$

Consider next an on-screen announcement prior to the airing of a television program that its broadcast to viewers' homes is conditional on their agreement not to engage in private home taping. Assuming the threshold determination that the viewers' decision to watch it notwithstanding the initial admonition constitutes a contractual bargain just as much as receiving software by wire, ${ }^{165}$ then the viewer's activation of her

160. See supra notes 34-36 and accompanying text.

161. The Seventh Circuit premises its ruling on the following language: "A contract for sale of goods may be made in any manner sufficient to show agreement, imcluding conduct by both parties which recognizes the existence of such a contract." ProCD, 86 F.3d at 1452 (quoting U.C.C. \$2204(1)). Judged by the standard of $\S 2-204(1)$, oral copyright transfers should be recognized. If the contrary force of 17 U.S.C. $\$ 204(a)$ is deemed to command the opposite result, then the question arises why the same U.C.C. section should not be overborne because of the contrary force of Feist, construing not only the Copyright Act but the requirements of the U.S. Constitution as well.

162. The drafters of Article $2 B$ concede that the doctrine of unconscionability should preclude "bizarre and oppressive results in standard form contracting." U.C.C. § 2 B-208 reporter's note 1 (Draft, Mar. 1998). But their notion of where oppression lies may differ markedly from ours, much less those applied by various courts.

163. 17 U.S.C. $\$ 101$ (1994).

164. It should be noted that the inotion-picture studios, at the outset of the videotape era, attempted to increase their rights through the legitimate methodology of lobbying Congress for a change to the first-sale doctrine. See 2 Nimmer ON Copyright, supra note 13, § 8B.01[B]. The studios previously concluded among thenuselves that unilateral leveraging of their rights through the shrinkwrap vehicles contemplated in the text would not withstand judicial review.

165. The Seventh Circuit singles out as valid those transactions where a customer purchases software over the Internet and receives it by wire. See ProCD, 86 F.3d at 1451. We have previously 
VCR constitutes breach of contract. Now, not only has the Supreme Court's Feist decision been effectively nullified-so has its ruling in Sony. ${ }^{166}$

In Sony, the Supreme Court stated that "[copyright] protection has never accorded the copyright owner complete control over all possible uses of his work."167 Yet in a world governed by Judge Easterbrook's radical freedom to impose terms by shrinkwrap "contract," there is no reason that such a conclusion should pertain. Instead, the imagination of shrinkwrap drafters can coine close indeed to achieving the type of complete control that Sony expressly denied them.

Consider the following example of that complete control. Although the Act limits the copyright owner's rights to "public" distribution, ${ }^{168}$ publishers who follow the logic of ProCD, Inc. v. Zeidenberg may amplify their statutory rights simply by wrapping books ${ }^{169}$ in cellophane, subject to the limitation that the buyer is barred from passing the purchased copy on to a friend. ${ }^{170}$ Nor is there any reason that the publisher should stop there. It could likewise require the reader not to skip chapters, not to read any paragraph more than three times, ${ }^{171}$ not to reveal the surprise plot twists to family or acquamtances, and certainly not to quote in a book review the few short excerpts that the fair use doctrine would otherwise permit. ${ }^{172}$

The foregoing examples represent simply the tip of ProCD's iceberg. For not only could Sony and Feist be nullified under its approach, but so could virtually every other court decision ever to rule in a defendant's favor.

noted our view that the instantiation thereby rendered onto the purchaser's hard drive constitutes a "copy" of the subject work. See supra Section II.B.

166. Sony Corp. of Am. v. Universal City Studios, Inc., 464 U.S. 417 (1984) (holding private home videotaping is fair use).

167. Id. at 432 .

168. See 17 U.S.C. $\$ 106(3)$ (1994). The parallel point just made in the text relates to public performance, as distinguished from public distribution.

169. Books fall into the same category of protection under the Act as did the software at issue in

ProCD: Each qualifies as a "literary work." See 17 U.S.C. § 102(a)(1) (1994).

170. The fear that copyright owners would be clothed with an expansive right to control "reading" of their materials in cyberspace has already been realized under this scenario, and in the mundane world of hard copies at that. See Jessica Litman, The Exclusive Right to Read, 13 CARDozo ARTS \& ENT. LJ. 29 (1994).

171. See David Nimmer, Adams and Bits: Of Jewish Kings and Copyrights, 71 S.C. L. Rev. 219, 226 n.37 (1998) (quoting whimsical copyright notice forbidding various usages - for instance, by reviewers unless they "promise to read the book painstakingly all the way through before writing their reviews").

172. See 17 U.S.C. \$ 107 (1994). The U.C.C. drafters actually come close to conceding this particular point: "[I]f a term in a widely distributed consumer magazine that purports to prevent a reader of the inagazine from using a factual summary or a brief quotation were structured to create a contract [it would pose] serious questions of enforceability under copyright and constitutional free speech considerations." U.C.C. \& 2B-105 reporter's note 3 (Draft, Mar. 1998). We agree, and would extend the same considerations to the software arena as well. See infra Section IV.B. 
The Supreme Court gave wide berth to the parody defense in Campbell v. Acuff-Rose Music, Inc. ${ }^{173}$ That defense essentially disappears once Roy Orbison and his fellow composers wrap their tapes and CDs in jewel boxes armed with the appropriate shrinkwrap language forbidding parodic exploitation. In another unanimous ruling during the same term, the Court held in Fogerty v. Fantasy, Inc. that attorney's fees need to be awarded evenhandedly to plaintiffs and defendants. ${ }^{174}$ But plaintiffs savvy to the options that ProCD affords can avoid that nettlesome limitation by adopting the expedient of wrapping their goods in packages that guarantee by contract treble awards of attorney's fees incurred for copyright infringement. ${ }^{175}$

Circuit courts have validated reverse engineering of software when undertaken for proper purposes. ${ }^{176}$ Merely by prohibiting that conduct under a shrinkwrap license, the nominally "fair use" is constricted out of existence. ${ }^{177}$

Before ending, one more example of recent vintage springs to mind. A unanimous Supreme Court has just rejected copyright proprietors' rights to bar certain parallel importations under the Copyright Act. ${ }^{178}$ That impediment need not deter those shampoo manufacturers and others who simply include with their products shrinkwrap licenses forever barring entry of the subject goods into the United States. Another Supreme Court precedent likewise bites the dust under ProCD's view of the law. The list could be multiplied endlessly.

However, each example in the foregoing parade of horribles differs in one critical respect from the facts of ProCD in that each involves interposing contract into the realm in which Congress had the ability to legislate. For example, Congress could have validated oral transfers of copyright. It could have defined "public performance" to mean performance before no more than three unrelated adults. It could have excluded parody from "fair use" and instead imposed a mandatory license scheme for all would-be parodists. ${ }^{179}$ It could have limited the

173. 510 U.S. 569 (1994).

174. 510 U.S. 517 (1994).

175. The Supreme Court noted that copyright's purpose is to protect the public interest; as such, delineating the bounds of copyright owners' rights is as socially useful as vindicating an infringement claim. See id. at 527. Again, that "delicate balance" is swept aside under the Seventh Circuit's exaltation of copyright owners' all-powerful contract rights.

176. See, e.g., Sega Enters. Ltd. v. Accolade, Inc., 977 F.2d 1510 (9th Cir. 1992).

177. Judge Easterbrook's praise of "a clause forbidding disassembly" as "procompetitive" suggests that this result represents the conscious intent of ProCD. See ProCD, 86 F.3d at 1455; see generally Robert A. Kreiss, Accessibility and Commercialization in Copyright Theory, 43 UCLA L. REv. 1 (1995).

178. See Quality King Distribs. Inc. v. L'Anza Research Int'l, Inc., 118 S. Ct. 1125 (1998).

179. For present purposes, we are sidestepping the inquiry as to whether the First Amendment itself affords parodic breathing space. See generally Neil W. Netanel, Copyright and a Democratic 
first sale doctrine effectively to bar all parallel imports. In other words, Congress could have made these choices, but it did not do so when it set the bounds of the "delicate balance" between that which enjoys copyright protection, and that which is free for all to use.

By contrast, ProCD deals with matters outside the ambit of Congress's legislative power as delimited by the Copyright Clause. For example, the text of the Copyright Clause makes it clear that Congress cannot grant copyright protection of indefinite duration. ${ }^{180}$ Feist makes equally clear that Congress is constitutionally barred under the Copyright Clause ${ }^{181}$ from giving copyright protection to alphabetical telephone listings, which by their nature fall below the constitutional threshold for copyrightability. ${ }^{182}$ It may be argued that the shrinkwrap license in ProCD therefore falls outside of the realm of preemption altogether because by definition it cannot "stand[] as an obstacle to the accomplishment of the full purposes and objectives of Congress."183

This facile argument overlooks the fact that a state law need not fall within Congress's authority under the Copyright Clause to interfere with the objectives of Congress. Consider, for example, a state law that provided as follows:

Upon expiration of the limited term of copyright granted by Congress in a particular work, the owner of the copyright shall, from the moment of copyright expiration forward into perpetuity, enjoy under the laws of the State of California the exclusive right to do and to authorize any of the following: (1) to reproduce the fornierly copyrighted work; (2) to prepare derivative works based on the formerly copyrighted work; and (3) to distribute copies of the fornerly copyrighted work to the public by sale or other transfer of ownership, or by rental, lease, or lending.

Civil Society, 106 YALE L.J. 283 (1996); Melville B. Nimmer, Does Copyright Abridge the First Amendment Guarantees of Free Speech and Press?, 17 UCLA L. REv. 1180 (1970).

180. See U.S. CoNST., art. I, § 8, cl. 8 (authorizing Congress to grant copyrights "for limited times").

181. An entirely separate question arises as to whether Congress has the power under the Cominerce Clause to give copyright-like protection to uncopyrightable materials such as alphabetical compilations of telephone histings. That is precisely what Congress may do should it pass currently pending database protection legislation. See Collections of Information Antipiracy Act, H.R. 2652, 105th Cong. (1998).

182. The Court in Feist held open the possibility that purloining of phone histings, under certain instances, could give rise to liability under the state law of unfair competition. See 499 U.S. at 354 (citing 1 NIMmer oN COPYRIGHT, supra note 13, § 3.04). Misappropriation of histings that constitute "hot news" or trade secrets spring immediately to mind in this context. Thus, we have no objection to a data provider such as NASDAQ maintaining exclusive control over stock histings for a limited period of time-amounting to days, for example. But cf. Joel Rothstein Wolfson, Contract and Copyright Are Not at War: A Reply to "The Metamorphosis of Contract into Expand," 87 CALIF. L. REv. 79, 88-98 (1999) (arguing that Article 2B is necessary to provide full protection for such data).

183. Hines v. Davidowitz, 312 U.S. 52, 67 (1941) (emphasis added). See supra notes 90-91. 
Strictly speaking, the foregoing law is outside the lawmaking authority of Congress under the Copyright Clause for, as noted above, Congress is constitutionally constrained to provide limited terms of copyright protection. But the foregoing provision would render meaningless the term limitations imposed by the Copyright Act and should therefore be viewed as "stand[ing] as an obstacle to the accomplishment of the full purposes and objectives of Congress"-copyright protection of limited duration. Similarly, the Feist-defeating provision of ProCD should be viewed as "stand[ing] as an obstacle to the accomplishment of the full purposes and objective of Congress"-extending copyright protection only to original works of authorship. Were that not the case, state law could effectively defeat all of the constitutionally generated limitations of the Copyright Act. Such a result would offend not only the Congressional scheme, but would run contrary to the design of the Copyright Clause itself. ${ }^{184}$

$* * *$

The Seventh Circuit's analysis of Supreme Court preemption cases further reveals the infirmities of its ruling. For instance, ProCD cites Kewanee Oil Co.v. Bicron Corp. ${ }^{185}$ a case in which the Supreme Court validated trade secret law. ${ }^{186}$ The point is well taken that the states are free to protect under that rubric materials that are otherwise uncopyrightable-an alphabetical customer hist, for example. ${ }^{187}$ Trade secret laws survive the "extra element" test and contravene no federal policy pertaining to copyright. For that reason, legions of cases rule that copyright law does not preempt trade secret causes of action. ${ }^{188}$

On the other hand, the same line of cases recognizes that it is only because those state laws limit protection to works held confidentially that they survive preemption; otherwise, the distinction between trade secret law and copyright would collapse, and trade secret law would be preempted under section 301 . Thus, to the extent that a state, as a matter of its own internal law, labels a published book of alphabetical telephone listings a "trade secret," the law would be invalid under the Supremacy Clause.

That last result exactly parallels ProCD's circumstances. Although labeled "contract under the Uniform Commercial Code" instead of

184. See Hoehling v. Universal City Studios, Inc., 618 F.2d 972, 980 (2d Cir. 1980) ("Where, as here, historical facts, thentes, and research have been deliberately exented from the scope of copyright protection to vindicate the overriding goal of encouraging contributions to recorded knowledge, the states are pre-empted from removing such materials from the public domain.").

185. 416 U.S. 470 (1974).

186. See ProCD, 86 F.3d at 1454 .

187. See id.

188. See 1 NiMmer ON COPYRIGHT, supra note $13, \S 1.01[\mathrm{~B} 1[1][\mathrm{h}]$. 
"trade secret," the state rights under examination were precisely congruent to those litigated (adversely to their claimants) in the copyright sphere. Thus, the Seventh Circuit's reference to trade secret law, far from proving its approach correct, in fact reveals the error of its way. ${ }^{189}$

Besides Kewanee Oil, the only other Supreme Court cases in the intellectual property arena that ProCD cites to explicate its preemption analysis are Aronson v. Quick Point Pencil Co. ${ }^{190}$ and Bonito Boats, Inc. v. Thunder Craft Boats, Inc. ${ }^{191}$ The former illustrates the general principle that contracts for non-commercialized goods deserve enforcement; it does not illuminate the commercialized goods at issue in ProCD. ${ }^{192}$

Moreover, the Aronson Court's efforts to distinguish its ruling from Brulotte v. Thys Co. ${ }^{193}$ cast further doubt on the Seventh Circuit's reasoning. Brulotte held that parties may not extend by contract the maximum federal term for patents. It therefore proves that freedom to contract intellectual property must bow before the federal policies implicated in that law-the precise point that the district court in ProCD attempted to vindicate.

Bonito Boats is even more powerful proof of how Judge Easterbrook's approach cannot stand. In Bonito Boats, a unanimous Supreme Court ruled that states lack the power to pass laws barring the plug-niolding of boat hulls. ${ }^{194}$ But under the logic of ProCD, relief for the losing plaintiff should be forthcoming under the state law of

189. As to trade secrets, their lack of public accessibility means that there is no imbalance to maintaining by contract a higher degree of protection than copyright law would otherwise afford. See Kreiss, supra note 177, at 6, 54-56. See also Dennis S. Karjala, Federal Preemption of Shrinkwrap and On-Line Licenses, 22 U. DAYTON L. REv. 511 (1997).

190. 440 U.S. 257 (1979).

191. 489 U.S. 141 (1989).

192. The subject contract in that case, far from being a shrinkwrap for a published product, was "freely undertaken in arm's-length negotiation" for a wholly confidential product (an ingemious keyholder). Aronson, 440 U.S. at 266. "In negotiating the agreement, Mrs. Aronson disclosed the design in confidence." Id. at 263 . Quick Point explicitly agreed to pay the negotiated consideration "in return for the use of a novel device which enabled it to pre-empt the market." Id. at 264. Parallel logic dictates that if ProCD had entered a negotiated agreement with Zeidenberg to disclose unexploited confidential phone listings, and Zeidenberg agreed "to pay for the opportumity to be first in the market," as did Quick Point ("an experienced novelty inanufacturer"), he could not invoke preemption to avoid his contractual obligations. Id. at 266. The essence of Aronson is that protection of information disclosed in a bona fide confidential relationship is not inconsistent with the federal patent and copyright laws. It is a far cry to suggest, as ProCD does, that an individual publisher can obtain similar rights by using the artifice of a shrinkwrap contract to manufacture a "confidential" relationship with thousands or millions of customers who pick its product off a shelf or wire.

193. 379 U.S. 29 (1964).

194. The House of Representatives recently passed a bill that would give a limited term of protection to boat hulls. See The Vessel Hull Design Protection Act, H.R. 2696, 105th Cong. (1998); 144 CoNG. REC. H1247 (daily ed. Mar. 18, 1998) (recording passage). 
contract, for the boat manufacturer simply needs to outfit its products with a shrinkwrap license forbidding plug-molding. ${ }^{195}$

A month after Bonito Boats was decided, Judge Easterbrook went on record condemning it as "a step in the wrong direction."196 There is nothing illegitimate about that point of view; it may one day turn the whole Court around. But it is quite another matter for the Seventh Circuit to write Bonito Boats-along with Feist, Sony, Campbell, Fogerty, and a host of other decisions - out of existence before that day has dawned. ${ }^{197}$

The threat from potential elimination of user rights through contract, moreover, is not limited to the world of shrinkwrap contracts. Greater freedom of contract should typically attach to negotiated contracts than to non-negotiated, or "mass market" contracts. This distinction is reasonable if, in the negotiated context, the potential licensee (or more generally, the potential recipient of copyright rights) can walk away and pursue other options. The distinction between negotiated and non-negotiated agreements breaks down, however, when all or significantly all access to copyrighted works is mediated through contracts purporting to control uses of the copyrighted work. ${ }^{198} \mathrm{~A}$ given copyrighted work (for instance, a particular operating system software for personal computers) may be de facto necessary to take advantage of hardware and software offered by other copyright owners. No matter how vigorously a potential licensee engages in an arms-length transaction about how she may use that operating system software, she ultimately lacks any real'option of seeking better terms from a different source. One can imagine, as in the cautionary tale spun at the start of

195. Indeed, given the vastly larger space available on a boat hull than on the exterior of a box encasing software, the manufacturer could write the whole contract in visible form, dispensing with the cellophane altogether.

196. Frank Easterbrook, Intellectual Property Is Still Property, 1 HARv. J.L. \& PUB. PoL'Y 108, 114-17 (1989) ("The proposition that one state's law concerning injection molding gave anyone a monopoly profit is hilarious."). The Court's later ruling in Feist extended the vector of Bonito Boats. See Rochelle Cooper Dreyfuss, A Wiseguy's Approach to Information Prodncts: Muscling Copyright and Patent into a Unitary Theory of Intellectual Property, 1992 SuP. CT. REv. 195. Given Judge Easterbrook's observation that "[i]solated cases are not influential," one imagines that he viewed the trend evidenced by both Supreme Court rulings as "a web of decisions," that he presumably would be happy to see unravel. See Easterbrook, supra, at 118.

197. In addition, one can add Brulotte as another Supreme Court case, Lasercomb from the Fourth Circuit, and Sega v. Accolade from the Ninth Circuit. It would not be a difficult exercise to extend the inconsistent thrust of ProCD to previous Seventh Circuit cases as well, such as Gracen $v$. The Bradford Exchange, 698 F.2d 300, 304 (7th Cir. 1983).

198. At present, most transactions for copyrighted works involve a straightforward sale, as opposed to a "license." The straightforward sale scenario involves contract law, but does not typically purport to affect the copyright rights of the end user. 
this Article, a market in which copyrighted works as a whole can only be accessed through contract. In these take-it-or-leave-it contexts, the lack of true choice means that the copyright owners' contract terms operate in effect as "private legislation" that serves to alter en masse the public's rights granted under the Copyright Act. ${ }^{199}$

One concern about undermining the holding of ProCD is that to do so exposes valuable databases of uncopyrightable materials to parasitic copying and undermines efforts to recoup investment costs through price discrimination. ${ }^{200}$ One must concede that if neither copyright law nor contract protects uncopyrightable but valuable databases from copying, the incentive to create such databases and the attendant social benefits of having such databases created may diminish. ${ }^{201}$ Accordingly, one may argue that it is socially desirable to offer protection for uncopyrightable databases ${ }^{202}$ and to foster price discrimination as an incentive to investment. ${ }^{203}$ But a unammous Supreme Court has recently

199. See Robert P. Merges, The End of Friction? Property Rights and Contract in the Newtonian World of On-Line Commerce, 12 BERKELEY TECH. L.J. 115, 126 (1997) (footnote omitted) ("[A] dominant contractual form can operate as a form of 'private legislation' that restricts federally conferred rights every bit as much as a state statute."). In the landmark case of Shelley v. Kraemer, 334 U.S. 1 (1948), the Supreme Court struck down racially restrictive zoning restrictions that, as a practical matter, controlled all the real estate of a locality and thus obtained the force of private legislation. Perhaps a similar mind frame should inform evaluation of those who dominate the "real estate" of the new space. See Alan Murray, It's Time Gates Placed Trust in Trustbusters, Wall ST. J, Mar. 9, 1998, at A1 ("Mr. Gates has managed to wm near-total control of the most valuable real estate in business today: His Windows operating system has become almost the sole entry point to cyberspace. He objects to such comparisons, but his business position is one that even John D. Rockefeller could envy.").

200. Plaintiff in ProCD engaged in price discrimination to recoup its $\$ 10$ million investment incurred by charging less to the general public for private use than to the trade. See ProCD, 86 F.3d at 1449. In order to make its price discrimination work, it had to prevent the type of arbitrage in which defendants engaged. See id. at 1450.

201. Nonetheless, the law of misappropriation can protect against purloining of "hot data." See supra note 182.

202. Many cominentators agree that because valuable databases have hittle protection under copyright law, it would be socially beneficial to provide greater protection to maintain the proper incentives for database creation, although they differ about precisely what form that protection should take. See, e.g., Hearings Concerning H.R. 2652, The Collections of Information Antipiracy Act, Before the Subcom. on Courts and Intellectual Property of the House Com. on the Judiciary, 105th Cong. (1997) (statement of Laura D'Andrea Tyson), available in 1997 WL 664842 ("Because technology has expanded the potential applications of databases to myriad research, educational, medical and business uses, the lack of adequate legal protections for the efforts of database providers poses a serious public policy challenge with widespread implications.”); J.H. Reichman and Pamela Samuelson, Intellectual Property Rights in Data?, 50 VAND. L. REv. 51, 55 (1997) ("[T]raditional intellectual property models, as supplemented by classical trade secret laws, often fail to afford those who produce today's most commercially valuable goods enough lead time to recoup their investments.").

203.

It is true that absent relief under contract law, sellers of CD-ROMs face a dilemma. A producer of movies segments the market by time, releasing first to theaters, then to pay-perview services, next to the videotape and laserdisc market, and finally to cable and commercial TV. Vendors of computer software have a harder task. [The type of arbitrage 
accorded no weight whatsoever to price discrimination as a basis on which to resolve dilemmas in copyright doctrine. ${ }^{204}$ Moreover, as the Feist court's abolition of the "sweat of the brow" doctrine should make clear, general considerations of social desiderata plainly cannot justify ignoring preemption problems of constitutional dimension. Result-oriented jurisprudence must be resisted, even if one believes the result correct. The solution to parasitic copying of historical ${ }^{205}$ databases, to the extent such protection is needed, ${ }^{206}$ is to be found in creating proper federal protection for uncopyrighted materials, not in encouraging a contract regime to perform an end-run around the limits of copyright.

in which defendants engagedl would break down the price discrimination and drive up the minimum price at which ProCD would sell to anyone.

ProCD, 86 F.3d at 1450 . It must be acknowledged forthrightly that, without the contractual relief that the Seventh Circuit enforced, it would have been difficult for ProCD to price its particular product cheaply to the general public. That difficulty, however, stenis in large measure from the fact that the commercial value of ProCD was based almost entirely on quintessential public domain information (alphabctical phone listings). In the case of works subjcct to copyright protection, such as the movies or computer software discussed in the passage quoted above, the copyright laws provide rights to proprietors (for instance, exclusive distribution, public performance) that are designed specifically to permit the types of price discrimination ProCD favors. Moreover, ProCD, Inc. may well have been able to avoid its difficulties simply by providing some origimal, value-added content, which would be subject to copyright protection (for example, embedding the phone number information in a proprietary database structure optimized for speed; adding additional original information to the listings; organizing the listings in an original way). By denying protection for the mere effort of collecting public doman information (the "swent" of ProCD's "brow"), the copyright laws create a powerful incentive to add value to existing information, rather than simply to repackage and distribute it. The present authors doubt that the nation would be better served by a system that protects compilations of public domain information at the expense of promoting new original expression; we nonetheless concede that this is a subject that mcrits its own extended treatment.

204. "[W] hether or not we think it would be wise policy to provide statutory protection for such price discrimination is not a matter that is relevant to our duty to interpret the text of the Copyright Act." Quality King Distribs., Inc. v. L'Anza Research Int'l, Inc., 118 S. Ct. 1125, 1134 (1998). The reasoning of Quality King applies a fortiori to ProCD. For in the former case each party could simply adduce one statutory provision favoring its position (17 U.S.C. $\$ 602(a)$ in favor of plaintiff, 17 U.S.C. $\S 109$ (a) in favor of defendant). The Court rejected plaintiff's policy argument that price discrimination tipped the scales between these two sections of the Copyright Act. But the latter dispute, by contrast, pits plaintiff's desire for price discrimination against defendant's defense of constitutional magnitude. Thus, the ProCD defendant's arguments are far more powerful than those which sufficed to convince the Supreme Court in Quality King.

205. We use the term "historical" to differentiate from "hot data." See supra note 182.

206. Critics of currently proposed database protection legislation point out that there is a dearth of einpirical evidence to support the claimed need for database protection. See, e.g., Hearings Concerning H.R. 2652, The Collections of Information Antipiracy Act, Before the Subcomm. on Courts and Intellectual Property of the House Comm. on the Judiciary, 105th Cong. (1997) (statement of Jerome H. Reichman), available in 1997 WL 662280 ("the rapid growth in the past few years of electronic databases of all kinds, including hundreds aimed at the scientific market, hardly suggests a lack of incentives."); Pamela Samuelson, Letter re: Tyson/Sherry Report (last inodified Apr. 30, 1998) <http://www.arl.org/info/frn/copy/psamlet.html> ("The gencral rule of 'if it ain't broke, don't fix it' would secm to apply here. It is striking how little empirical evidence has been offered thus far by proponents of database legislation of actual or threatened market failures that rcquire legislative action."). 
To conclude, if copyright law is to maintain an autonomous existence, mstead of becoming an adjunct to whatever lawyers can draft into shrinkwrap "contracts," then its delicate balance must be respected. For that reason, the Seventh Circuit's holding in ProCD, Inc. v. Zeidenberg, it is submitted, is im error.

\section{Framework of Preemption Principles: To the Limits of Monopoly}

From the foregoing discussion, it should be clear that contracts can not only coexist within the overarching copyright framework, but are essential for its proper implementation. Because U.S. copyrights are infinitely divisible, contract is the only sensible means for dividing up spheres of exploitation. On the other hand, those convinced by the foregoing discussion can harbor no doubt that not every device unilaterally imposed under the rubric "contract" can pass constitutional muster. ProCD v. Zeidenberg clearly illustrates that phenomenon. The question therefore remains where the dividing line lies between the perinissible and the forbidden.

Abstracting from the above criticism of the Seventh Circuit's decision in ProCD, the appropriate dividing point emerges orgamically from the copyright monopoly that Congress, acting within the framework of the Constitution, bestows upon authors. If a copyright owner contracts to exploit a work up to the linits of his constitutionally and congressionally conferred monopoly, he is acting legitimately; conversely, if an author uses contract law to enlarge that monopoly to apply to exploitations beyond its congressionally sanctioned orbit, she is behaving illegitimately. That latter conclusion follows whether the expansion derives directly from state law $w^{207}$ or as a matter of contract law, which ultimately derives its enforceability froin the saine body of state law.

$$
* * *
$$

To illustrate, let us imagine several scenarios, each applicable to the new entity that hypothetically has purchased all right, title, and interest in and to the MGM classic, Gone with the Wind.

Series (i):

- The owner grants A a license to screen the film theatrically, limited to theaters located on the south side of Pico Boulevard in Los Angeles.

207. As a direct example of that phenomenon, see College Entrance Examination Board. v. Pataki, 889 F. Supp. 554 (N.D.N.Y. 1995) (evaluating whether New York state law may legitimately require testing service to reveal the expression underlying its copyrighted examinations). 
- B receives a license to engage in theatrical distribution anywhere in the United States, but limited to alternate Tuesdays during leap years.

- C bargains for a license to engage in worldwide ${ }^{208}$ distribution by videotape, for a period of three weeks only, at a $6 \%$ royalty.

- D purchases rights of television broadcast in the Cambodian-dubbed version. ${ }^{209}$

- E sews up all rights to Gone with the Wind in DVD format.

- $F$ is the lucky winner of the same rights in $C D++$ format.

Series (ii):

- G receives the right, after C's three weeks expire, to engage in distribution of videotapes at the same $6 \%$ royalty, which $\mathrm{G}$ agrees to pay for a term of 100 years.

- $\mathrm{H}$ receives the right to engage in theatrical screenings on the north side of Pico Boulevard and throughout the rest of Los Angeles. However, as a condition for granting that license, the proprietor insists that $\mathrm{G}$ also pay a like amount to license Night of the Lepus.

- MYRRHA stands as guardian to the portals of all copyrightable compositions. ${ }^{210}$ In order to see Gone with the Wind, viewers must pay the current freight, set at $\$ 5$ for each 37-minute segment. A comparable charge is imposed for Night of the Lepus and every other motion picture. Novels and poems are also metered through MYRRHA, albeit subject to a different tariff table.

Series (iii):

- The proprietor of Gone with the Wind has waited past the expiration of the film's term. Nonetheless, taking advantage of MYRRHA access gates, it charges the same rates at present as were previously imposed for anyone to make home copies of the work.

- In addition, the proprietor takes out a license in the menu tree of Lotus 1-2-3, invoking MYRRHA's technology to impose on software developers a surcharge for incorporating that time-tested model into their latest products.

Series (iv):

- I receives a license to display a still frame from the film in connection with news reports surrounding Clark Gable's obituary. ${ }^{211}$

208. For purposes of the current analysis, nonetheless, the impact of contracts is treatcd solely within the borders of the United States.

209. Cf. Gamma Audio \& Video, Inc. v. Ean-Chea, 11 F.3d 1106 (1st Cir. 1993) (determining that plaintiff owned derivative Cambodian translation of underlying Chinese motion picture).

210. See the cautionary tale at the outset of this Article.

211. For current purposes, let us imagine that Clark Gable is still alive and that the license applies prospectively. 
- $\mathrm{J}$ receives a license to screen ten seconds of the film in conjunction with her UCLA seminar on great filins froin the heyday of Hollywood.

- $\mathrm{K}$ buys a shipment of 5000 videotapes of the filin, each wrapped in a shrinkwrap license forbidding any and all uses in Nevada, even if such qualify as "fair uses" under applicable law.

In analyzing the permissibility of all of the contracts hypothesized above, our fundamental axiom furnishes the answer, at least to the first three series: contracts are legitinate up to the full extent of the copyright owner's monopoly as sanctioned by Congress, and are illegitimate to the extent that they exceed the bounds of that monopoly.

\section{Permissible Limitations}

Series (i) represents the uncontroversial cases. The Copyright Act grants proprietors the exclusive right to do and to authorize each of the affected activities. Accordingly, those six contracts should each find enforcement under the copyright regime.

\section{Misuse and Related Notions}

Moving to series (ii), the grant to $G$ binds that licensee to pay royalties for a century into the future, long after the film's copyright will have expired. That contractual term is illegitimate, as ruled by the Fourth Circuit im a landmark case curtailing the legitimate scope of contracts over copyrightable compositions-even those bargained for by both contracting parties. ${ }^{212}$

A point of terminology is in order here. Although the landmark case just cited labeled the contract infirm under the doctrine of "copyright misuse," that tern is redolent of antitrust law. It is true that instances of antitrust violations represent one particularly egregious instance of illegitimate behavior, but the doctrine nonetheless should not be limited to that sphere. ${ }^{213}$ The fatal flaw against which the Fourth Circuit reacted is that the copyright owner there was seeking judicial enforcement of a contract that explicitly contravened the user limitations incorporated by Congress into the Copyright Act, not that it was acting in violation of the Clayton Act or the Sherman Act. Based on the elaborate edifice constructed above, it is submitted that the rubric of

212. Lasercomb Am., Inc. v. Reynolds, 911 F.2d 970 (4th Cir. 1990). It would seem that the U.C.C. is attempting to overrule Lasercomb by presumptively validating perpetual contractual use restrictions. See U.C.C. $\S 2$ B-308(2) (Draft, Mar. 1998). If $\S 308$ were in effect today, a contractual restriction on reproducing Windows 95 included in the accompanying shrinkwrap would presumptively be enforceable 150 years hence, long after the software would have passed into the public domain under current law. Congress has just amended the Copyright Act to extend terms, under the Sonny Bono Term Extension law.

213. Lasercomb recognizes as much. See Lasercomb, 911 F.2d at 978. 
"preemption" better describes the contract's infirmity than does "misuse."

Nonetheless, to the extent that an antitrust violation is present, the same result should mure a fortiori and the subject contract must be denied enforcement. We thus reach $\mathrm{H}$, in which the copyright proprietor has engaged in what appears to be an illegal tying agreement (assuming, for the sake of discussion, that the requisite requirements for market power in the market for the tying good are met and that buyers would not otherwise license Night of the Lepus). ${ }^{214}$ That improper behavior results in the invalidation of the subject license.

Moving now to MYRRHA, one can envision a variety of other potential antitrust violations, from tying to monopolization to price fixing. Insofar as the facts support a finding of an antitrust violation, the MYRRHA licenses must be denied enforcement by virtue of the illicit goals they atteinpt to achieve.

\section{Within the Subject Matter of Copyright Even as to Unprotected Works}

Under the Constitution, as we observed earlier, federal copyrights endure for terms of limited duration, after which public policy demands that the subject expression repose in the public domain. We have already reviewed why state law cannot attempt to accord protection anew on such lapsed works. ${ }^{215}$ Could proprietors nonetheless unilaterally achieve the same result by wrapping their expired works in self-styled proclamations of resurrection or in the other devices hypothesized in series (iii)? Because such devices would render the "limited times" provision of the Constitution a nullity, they cannot stand.

The same consideration governs the other usage hypothesized in series (iii) concerning the Lotus spreadsheet. That work likewise lies outside the limits of Congress' ambit to protect. ${ }^{216}$ To allow the U.C.C. or other devices enforced under guise of state law to achieve the contrary result agam vitiates the federal scheme and, as such, cannot stand.

\section{Difficulty of Drawing the Lines of Fair Use}

As always, issues at the boundaries can bedevil application of any straightforward standard. In this particular application, copyright's

214. Cf. Data Gen. Corp. v. Grumman Sys. Support Corp., 36 F.3d 1147, 1169 (1st Cir. 1994) (determining that Lasercomb could extend to tying under appropriate facts).

215. See supra Section III.C.2.

216. See Lotus Dev. Corp. v. Borland Int'1, Inc., 49 F.3d 807 (1st Cir. 1995), aff'd by an equally divided court, 116 S. Ct. 804 (1996). That ruling arises under the statute. See 17 U.S.C. § 102(b) (1994). But we submit that Congress lacks authority under the Constitution to accord copyright protection to systems, methods, and concepts. See Baker v. Selden, 101 U.S. 99, 102 (1879). 
infinitely elastic doctrine of fair use can pose its share of mischief. We thus reach series (iv).

In the abstract, it would seem perfectly straightforward that use of a single frame of Gone with the Wind from the hundreds of thousands of frames that comprise the picture-and for the purpose of illustrating the newsworthy event of reporting the death of its leading man-qualifies as fair use. By the same token, showing a few seconds to a film school class would similarly seem to qualify. Solely from that perspective, the licenses to I and J must be stricken as illegitimate.

To spell out the foregoing perspective, the analysis runs as follows: First, a copyright owner is only entitled to exploit her monopoly, not to expand it. Given that the statute itself carves fair use out of the scope of monopoly granted the copyright owner, 217 the copyright owner cannot require a user to contract out of fair use. Because the licenses to I and J deal with a use that ex hypothesi qualifies for the label of fair, these contracts are overreaching.

The fly in the ointment here is that fair use is notoriously difficult to ascertam in the abstract. Indeed, one usually cannot know whether or not a use is fair until litigation is resolved at the level of the U.S. Supreme Court. ${ }^{218}$ For that reason, it may be wise in almost any circumstance to license a work rather than roll the dice in a lengthy judicial process. Particularly when one reflects that cases have held against fair use in the selling of coursepacks destined for educational purposes, ${ }^{219}$ and even in the context of using short clips for seemingly highly newsworthy events, ${ }^{220}$ the vector towards settling rather than fighting takes on tremendous magmitude. Accordingly, the conclusion follows that the licenses to I and J should not be deemed illegitimate. Instead, because a court might in fact confound expectations by ruling the subject utilizations outside the fair-use doctrine, it is reasonable for two consenting

217. See 17 U.S.C. $\$ 107$ (1994).

218. "The malleability of fair use emerges starkly from the fact that all three [U.S. Supreme Court fair use] cases were overtumed at each level of review, two of them by split opinions at the Supreme Court level." 4 NIMMER ON COPYRIGHT, supra note I3, § 13.05 (footnotes omitted).

219. See Princeton Univ. Press v. Michigan Document Servs., Inc., 99 F.3d I381 (6th Cir. 1996) (en banc) (vacating previous panel decision over five dissenting judges), cert. denied, $117 \mathrm{~S} . \mathrm{Ct} .1336$ (1997).

220. See Roy Export Co. Estabhishment v. Columbia Broad. Sys., Inc., 503 F. Supp. 1137, 1148 (S.D.N.Y. 1980) (concluding that the unauthorized broadcast of selections from Charlie Chaplin motion pictures at the time of Chaplin's death could not be defended on First Amendment grounds, inasmuch as the only relevance to the news story regarding his death was not in the events depicted $\mathrm{m}$ the filıns but in the fact that the films had been made). Even more startlingly, Los Angeles News Service v. KCAL-TV Channel 9, 108 F.3d 1119 (9th Cir. 1997), held outside the fair use doctrine a news station's broadcast of an extraordinarily timely news segment concerning the then-unfolding Los Angeles riots. See also Los Angeles News Serv. v. Reuters Television Int'1, Ltd, 942 F. Supp. 1265, 1272-74 (C.D. Cal. 1996). 
parties to contract now to pay an ounce of royalties in order to avoid many pounds of attorneys' fees later.

On the other hand, the fair-use doctrine cannot be ignored in the calculus of permissible contracts. The license to $\mathrm{K}$ makes no bones about explicitly contravening it. In this particular instance, fine judgments as to future predictions need not take place, for the contract itself eliminates rights guaranteed to users by statute under any view of its appropriate construction. ${ }^{221}$ The license, therefore, is impermissible.

Turning to the nore vexing issue of reverse engineering, we would argue that the same considerations apply as in license $\mathrm{K}$ considered above. In other words, to the extent that a shrinkwrap contract for a commercialized good required blanket waiver of any and all reverse engineering rights, it should be deemed preenipted. Precedent up to the circuit court level has upheld that activity, when appropriately undertaken, as falling within the fair-use doctrine. ${ }^{222}$ Although the argument remains that the U.S. Supreme Court might ultimately reject that construction, until it does so those circuit-court pronouncements should be deemed declarative of the law. On that basis, a blanket diminution of user rights as defined by governing construction of the statute runs afoul of the prinuary axiom against illegitimate expansion of the copyright owner's monopoly.223

IV

SOME LESSONS FOR THE U.C.C.

At this juncture, it is legitimate to inquire what standards should inform a sensible drafting of U.C.C. rules. It will be recalled that those rules govern state contract formation, that such state law contracts form an essential ingredient in the scheme of federal copyright exploitation, but that certain state law contracts go too far. The question posed is the extent to which Article $2 \mathrm{~B}$ successfully mediates the potential clash between copyright and contract.

221. "Although the traditional approach is to view 'fair use' as an affirmative defense, this writer, speaking only for himself, is of the opinion that it is better viewed as a right granted by the Copyright Act of 1976." Bateman v. Mnemonics, Inc., 79 F.3d 1532, 1542 n.22 (11th Cir. 1996) (Birch, J.).

222. On the contours of the right, see 4 NIMMER ON COPYRIGHT, supra note $13, \S 13.05[D][4]$.

223. In our experience, we have seen shrinkwrap licenses-and even negotiated contracts - that purport to bar reverse engineering for any purpose whatsoever. If cnforced, bizarre results would inure. Imagime that $P$ imposes such a license term, to which $Q$ agrees. Imagine further that, some months into the license period, $Q$ hears an allegation from a former programmer at $P$ that the subjcct product has lifted whole chunks from Q's source code. In order to perform the rcquisite Rule Il investigation, $Q$ would need to reverse engineer P's software to determine if such copyright infringement (patent infringement is equally conceivable) has in fact occurred. Can it honestly be maintained that Q's developinent of an iron-clad case of copyright infringement would leave it liable to contract dainages to $P$ ? 


\section{A. The Neutrality Myth}

The drafters of Article 2B are well aware that transactions in "information" are rife with the potential for clash between copyright and contract. Theirs is an awareness born of abundant recent experience. Distribution of software, the quintessential "information" product, does not typically transpire as a classic sale of a copyrighted article, such as occurs when an end user purchases a copyrighted novel. In that classic sale context, the end user is free to make use of the purchased product, to sell it, lend it, annotate it, all subject only to the constraints of the Copyright Act.

Copyright owners of software, by contrast, increasingly do not simply sell a tangible embodinent of their copyrighted work - a diskette or CD-ROM - and do not rely on the Copyright Act alone to constrain the end user. Rather, by selling "goods" intangibly, such as via "clickwraps" executed over the Internet, they seek to interpose a licensing relationship with the end user as an absolute prerequisite to access and use. Even without that mstrumentality, they still sell tangible goods via a purported contract designed to create a licensor/licensee relationship. The familiar name for that device, as we have seen at length, is the "shrinkwrap license." 224

The preemption issue arises in an acute form in the shrinkwrap arena-and thus for Article $2 \mathrm{~B}$-because of the attempted use of shrinkwrap licenses to create an intellectual property regime based on contract law that enlarges the copyright holder's rights by denying users their rights under the Copyright Act. In this parallel universe of contract-created "copyright plus," the copyright owner enjoys all of the benefits conferred by the Copyright Act, while users are required to forfeit some or all of the rights secured to them under the Copyright Act, such as the right to make fair use of the work without the copyright owner's permission. ${ }^{225}$

The theoretical brake against imperialistic aspirations here is preemption, which (as discussed above) forbids state law from undernining the intellectual property scheme created by Congress. But the current draft of U.C.C. Article 2B largely avoids any attempt to limit copyright contracts so as to respect the preemptive boundaries of copyright. Instead, the drafters have adopted the position that "Article 2B should not deal with federal preemption but should be neutral" and that that position should be stated in the comments. ${ }^{226}$ Implementing this principle of "neutrality," Article 2B directly addresses preemption only by

224. See generally Mark A. Lemley, Intellectual Property and Shrinkwrap Licenses, 68 S. CAL. L. REv. 1239, 1259-63 (1995).

225. See supra Part II.

226. U.C.C. \& 2B-105 votes and action b. (Draft, Mar. 1998). 
providing, "[a] provision of this article which is preempted by federal law is unenforceable to the extent of such preemption."227

But the professed goal of neutrality is not one that the drafters of Article 2B consistently attempt to achieve. For instance, the March Draft for Article 2B consciously departs from the model for sales of goods under U.C.C. Article 2, in order to bring the former into harmony with "clear rules of federal law."228 Implementing that approach, the draft attempts to accommodate the Copyright Act's requirement of a writing in order to transfer ownership of a copyright. ${ }^{29}$ Similarly, Article 2B departs from the good-faith purchaser rules of state law, because copyright law offers no such defense to claims of infringement. ${ }^{230}$ Furthermore, the draft follows the copyright cases that have held that the licensee's interest is not transferable without the licensor's consent despite the fact that this rule contradicts some state law assumptions about transferability. ${ }^{231}$

Instead, the U.C.C. drafters purport to reserve their strategy of "neutrality" - that is, doing nothing affirmative-only for "controversial or context-determined rules whose application cannot be predicted and must of necessity await determinations by individual courts in particular cases or by Congress as a general federal policy question." 232 In other words, the draft is "neutral" only where it chooses to be..$^{233}$

227. Id.

228. Id. § 2B-105 reporter's note 1 (Draft, Mar. 1998) (emphasis added).

229. See id. § 2B-201 (statute of frauds); see also id. Preface at 10 ("[Clopyright law precludes a transfer of ownership of copyright in the absence of a writing conveying ownership. In discussing development contracts, this Draft reflects that limitation ....").

230. See id. $\S 2 \mathrm{~B}-508$ (determining that there is no bona fide purchase defense for transference of license).

231. See id. $\S 2 \mathrm{~B}-502$ (stating that the transfer of license rights is ineffective without licensor's consent); see also id. § 2B-502, reporter's notes (stating that $\$ 2 \mathrm{~B}-502$ follows "federal case law" and "federal policy").

232. Id. § 2B-105 reporter's note 4. Examples of such purportedly controversial issues are "reverse engineering of copyrighted, but unpatentcd technology and ... the scope of educational or scientific fair use of digital works." Id. One could reasonably question whether fair use reverse engineering, or fair use of digital works are truly controversial. Fair use is a fact-specific inquiry, but it cannot be that reverse engmeering and use of digital works without the permission of the copyright owner is never fair use. What is controversial is whether a copyright owner can deny the public its fair use rights through a shrinkwrap license. See supra Part II.

233. One commentator has wryly described Article $2 B$ as "afflicted with a severe case of multiple personality disorder when it tries to articulate its relationship with federal copyright law." Jessica Litman, The Tales That Article $2 B$ Tells About Its Connection with Copyright, 13 BERKELEY TECH. LJ. (forthcoming Dec. 1998) (manuscript at 1, on file with authors). Elaborating on the draft's lack of true neutrality, she observes:

Article 2B ... selectively incorporates copyright terns and decisions it likes, while encouraging the abandonment of those it does not. It accomplishes this trick by insisting that some copyright principles are invariable and inviolate, and the provision of Article $2 \mathrm{~B}$ must therefore be designed to accommodate them. Other copyright principles would constrain Article 2B licenses only in cases where the license transgresses "specific, existing and recognized limits" imposed by federal law, which the Preface assures us would be rare. 
One criticism of this purportedly "neutral approach" is that it is otiose. By simply restating im state law the constitutionally mandated effect of preemption as contained in the U.S. Constitution, it accomplishes nothing more than the exact same result that would inure even in its absence. ${ }^{234}$ In particular, it does nothing to elucidate what is preempted or to forestall contractimg behavior that is impermissible in light of the supremacy of copyright.

Further, as a practical matter, this selective "neutrality" suffers from precisely the same shortcoming of political neutrality in response to real-world conflict:235 it de facto favors those with concentrated interests and large fmancial resources and thus tacitly invites abuses. By taking no position on preemption other than that "it preempts," the draft ratifies the status quo and makes every imaginable shrinkwrap encroachment on users' rights presumptively enforceable. It thus forces into the arena of litigation any determination of whether a given license or portion thereof overreaches the supreme bounds of copyright.

The displacement into litigation of allegedly controversial issues favors vested interests over a diffused public whose members lack both the resources and incentives to litigate. In addition, the draft favors the contraction of user rights over the public's right to make fair use of copyrighted materials and to use freely what lies in the public domain. It is in this sense that the metamorphosis from "contract" to "expand" becomes inost apparent.

Finally, a third category of copyright principles seems to reflect ideas that the drafters of Article 2B find attractive, but find susceptible of improvement.

Id. at 9 (citations oumitted). See also Mark A. Lemley, Beyond Preemption: The Law and Policy of Intellectual Property Licensing, 87 C ALIF. L. REV. 111, 118 n.14 (1999) ("Article 2B has claimed a posture of 'aggressive neutrality' with respect to federal intellectual property law. In fact, however, a change in the terms of contract law necessarily will affect the contract-intellectual property interface. Such a change cannot be considered 'neutral' in application, even if it is neutral in intent ..."); J.H. Reichman and Jonathan A. Franklin, Privately Legislated Intellectual Property Rights: The Limits of Article 2B of the U.C.C. 19 (1998) (unpublished manuscript, on file with authors) ("[W] the power to impose non-negotiated license terms, it produces contracts ... that are roughly equivalent to private legislation .... This combination of powers makes a mockery of the drafters' pious claims that 'nothing in Article 2B is intended to alter the balance between federal mandates and contract principles' and that Article 2B 'takes no position' concerning controversial issues pertaining to the interface between state and federal law. Whether intended or not, the opposite is true.").

234. An alternative approach to addressing preemption in Article $2 \mathrm{~B}$, which previously enjoyed significant support, was to amend $\S 2 \mathrm{~B}-308$ (mass market licenses) to provide that a term inconsistent with federal copyright law does not beeome part of a contract under $\$ 2 \mathrm{~B}-308$. But this approach too fails to advance the ball beyond the unassailable proposition that preempted provisions of a contract are not enforceable.

235. In Dante's Inferno, the souls of the dead who avoided choosing between good and evil while alive endlessly circle the gates of hell: "The wretched souls of those who lived without infauny and without praise maintain this miserable mode." Dante Alighieri, The Divine Comedy 4 (Charles Eliot Norton trans., Encyclopaedia Brittanica 1952). 
The draft's justification for not taking an affirmative stand on allegedly "controversial" issues is that they "must be resolved by courts and Congress, rather than through state legislation." 236 That proposition itself is suspect, as the two hypothetical bills discussed below demonstrate.

\section{B. How the U.C.C. Might Help Maintain the "Delicate Balance"}

One must concede, of course, that Article 2B cannot anticipate every contract or context in which issues of preemption will arise and provide an a priori fix. But limiting the focus for the moment to copyright preemption, why could Article $2 \mathrm{~B}$ not at least address the means by which licenses have been used to alter the "delicate equilibrium"that is, the known evils? Let us assume, for example, that the next draft were to take an affirmative stand on copyright preemption by incorporating the following language, which has been proposed as an amendment to the Copyright Act:

\section{Boucher Bill:237}

Respecting copyright's delicate balance-When a work is distributed to the public subject to non-negotiable license terms, such terms shall not be enforceable... to the extent that they: (1) limit the reproduction, adaptation, distribution, performance, or display, by ineans of transmission or otherwise, of material that is uncopyrightable under section 102(b) [of the Copyright Act] or otherwise; or (2) abrogate or restrict the limitations on exclusive rights specified in sections 107 through 114 and sections 117 and 118 of [the Copyright Act].

Although the foregoing language is not presented as the "silver bullet" to eliminate preemption problems, it would at a minimum specifically address at least one preemption concern identified by the current draft as too controversial: reverse engineering. Given that case law upholds certain species of such reverse engineering as defensible under the fair use doctrine codified in section 107 of the Copyright Act, the Boucher Bill would clarify that a reverse engineering prohibition in a shrinkwrap license is unenforceable to the extent that it abrogates or limits the statutory fair use privilege. ${ }^{238}$

More fundamentally, an Article 2B incorporating the Boucher Bill would generally safeguard users' rights by rendering unenforceable provisions of licenses that seek to alter the "delicate equilibrium" that

236. U.C.C. art. 2B Preface at 10 (emphasis added).

237. Rep. Rick Boucher of Virginia introduced this language in a bill to the U.S. House of Representatives in the current session. See Digital Era Copyright Act, H.R. 3048, 105th Cong. (1998).

238. As previously noted, Judge Easterbrook intended the ProCD holding to reach the contrary result. See supra note 177. 
the Copyright Act establishes between the rights of copyright owners and the rights of the public. Because it is salutary, this hypothetical feature of a newly revised U.C.C. debunks the notion that debates in this sphere "must be resolved by courts and Congress, rather than through state legislation." 239

The foregoing thought experiment ${ }^{240}$ reveals no reason why Article $2 \mathrm{~B}$ could not adopt the foregoing proposed language, thereby taking a non-neutral stand on how preemption limits freedoin of contract. The bare fact that the U.C.C. drafters would thereby be "taking sides," by itself, is unobjectionable: choices are inevitable and neutrality usually a chimera. Indeed, Article $2 B$ self-consciously inakes choices in numerous domams to confer differential benefits on different constituencies. ${ }^{241}$

The fact that the language proposed above overtly addresses preemption concerns is also unobjectionable. For as previously noted, Article $2 \mathrm{~B}$ consciously carves out exceptions to its scope im deference to what it deems to be "clear rules of federal law." Moreover, the draft expressly states that if anyone desires to challenge its provisions as an impermissible, or indeed preempted, state encroachment on the federal scheme, he or she is free to seek redress in the "courts and Congress."

The legitimacy of the thought experiment contained in the Boucher Bill, which is premised on respect for copyright law's delicate balance, emerges further when it is contrasted with a hypothetical addition to Article 2B designed for the opposite purpose, that is, one that subverts that balance. As we have noted above repeatedly, the problem with the current draft of Article $2 B$ is that it presumptively validates provisions which impermissibly tilt in favor of proprietors. To appreciate why that one-sidedness is illegitmate, let us entertain conversely a hypothetical provision crafted to enlarge users' rights, that is, for the opposite purpose from the current draft:

239. One defect in the Boucher Bill, nonetheless, is its reliance on the concept of "nonnegotiable license forms." As discussed above, the distinction between negotiated and non-negotiated licenses is often meaningless in the preemption context. See also Wolfson, supra note 182, at 94-97 (criticizing distinction between negotiable and non-negotiable forms).

240. One critic of an earlier draft of this Article elevates our thought experiment entertaining the Boucher Bill into a specific "proposal," which he then proceeds to attack at length. See id. In response, we have attempted to clarify in the text and notes above that we do not adopt the Boucher Bill as our own proposal. Instead, the purpose of our thought experiment, based on the text of a pending federal bill, is to refute the clain that the drafters of Article 2B had their hands tied froin affirmatively addressing preeinption issues. This Article does not pretend to offer a fully developed and concrete proposal of the final language that the drafters of Article 2B should adopt.

241. The draft's Preface lists the benefits of Article $2 B$ as falling into the following categories: General Benefits; Licensor Benefits; Licensee Benefits. It thus tacitly acknowledges that while Article 2B may seek to strike a fair balance between licensor and licensee rights, its individual provisions are not neutral in how they confer benefits. 


\section{Charcutier Bill:}

Solicitude for the downtrodden-When a work is distributed to the public subject to non-negotiable license terms, such terms shall not be enforceable unless the licensor: (1) grants the licensee the right to reproduce an unlimited number of copies for persons falling below the poverty line as defined in the pertinent provision of the Code of Federal Regulations; and (2) agrees that he or she will not seek more than $\$ 300$ for any copyright infringennent committed by an orphan, widow or widower or by an individual adjudged "insane" pursuant to the laws of the state in which the alleged infringement occurred.

It should be patently obvious that the language just proposed is preempted and hence unenforceable, for it baldly encroaches on the exclusive rights granted to authors under the Copyright Act.242 One hopes that the drafters of Article $2 \mathrm{~B}$ would peremptorily dismiss the Charcutier Bill as slop, even were massive lobbying brought to bear for its adoption.

Parallel considerations dictate that license provisions should also be deeined preempted when they effect a blatant encroachment on the rights of users; for exainple their right to reproduce, adapt, distribute, perform, or publicly display inaterial that was once copyrighted and the term for which has lapsed, or the right to make fair use of a copyrighted work. It is here that the current draft of Article 2B needs fixing. By failing to protect even those obvious user rights and by blessing as presumptively valid provisions that would rob users of their rights, Article $2 \mathrm{~B}$ 's "neutrality" in effect tilts towards a regime that could be condemned as no less absurd than the Charcutier Bill hypothesized above, when both are viewed from the perspective of rights that Congress has denied to copyright owners and thus reserved to users. Better than either the pro-proprietor tilt of the current draft or the pro-user tilt of the Charcutier Bill, what is needed is respect for copyright law's delicate balance. Though the Boucher Bill itself is concededly not a panacea, it at least points in the right direction for a balanced reformulation of Article 2B's stance on preemption.

Some proponents of the draft's current "neutrality" have suggested that it would be a mistake to build specific preemption-driven restrictions into Article $2 \mathrm{~B}$, because this will force state courts into the quagmire of preemption analysis, a task that they view as properly left to the federal courts as the usual arbiters of interpreting the Copyright Act and its interrelationship with other laws. This leave-it-to-the-feds

242. Cf. Storer Cable Communications v. City of Montgomery, 806 F. Supp. 1518 (M.D. Ala. 1992) (holding that Copyright Act preempted Alabama city ordinance ruling exclusive licenses of cable programming illegal on antitrust grounds). 
argument is built on the fallacy that copyright preemption issues can be neatly cabimed within federal venues. In reality, as a necessary adjunct of resolving contract disputes, state courts cannot avoid making determinations regarding whether copyright law preempts particular contract provisions. ${ }^{243}$ Under an Article 2B regime, state courts still will not be able to avoid determining whether given contracts (or contract terms) are preempted if the defense is raised. Accordingly, Article $2 \mathrm{~B}$ can be silent on the issue, and offer no guidance (the faux "neutral" position), or it can offer some guidance by ruling out as unenforceable contract terms whose very purpose is to recalibrate the "delicate balance." The faux-neutral strategy does not eliminate adjudication of preemption issues in state court. Rather, it guarantees that state courts will face preeinption questions more frequently and on a broader range of issues.

A second leave-it-to-the-feds argument adduced by the proponents of faux neutrality is that questions of what should be preempted, to the extent addressed in legislation, are best left to Congress. As noted above, what is really being advocated is selective "neutrality" about the relationship between Article 2B and federal law. For in numerous particulars recounted above, Article $2 \mathrm{~B}$ is consciously crafted to be in harmony with the supremacy of federal law. Given that the drafters of Article $2 B$ clearly have the ability to take into account issues of federal law and that they do so when they wish to, their antagonism to Article $2 \mathrm{~B}$ forbidding certain overreaching contracting practices on preemption grounds smacks of tendentious selectivity. At a bare minimum, they should clarify why they have singled out this particular issue as the federal-law question to be ducked, particularly when it is reasonably certain that precisely the evils contenuplated herein (for example, attempting to contract away fair use) will take place if not curbed. The worst that can be said about implenienting himits on contracting practices designed to restrict known evils is that if such contracts are really not preempted, copyright proprietors will not be able to enjoy fully the freedom to contract-or at least will have to fight to do so. ${ }^{244}$ Copyright law itself will not suffer. By contrast, a failure in the other direction threatens to impinge directly on the federal copyright scheme.

243. As cited above, state courts must of necessity apply 17 U.S.C. $\$ 301$ in evaluating the constitutionality of the cause of action before them. See supra notes 129 (citing PMC, Inc. v. Saban Entertainment, Inc., 52 Cal. Rptr. 2đ 877 (Cal. Ct. App. 1996)) and 152 (citing Griggs v. South Carolima Elec. and Gas Co, 463 S.E.2d 608 (S.C. 1995)).

244. The burden under the current draft of challenging overreaching contracting practices is placed upon users. By contrast, under the scheme outlined above, proprietors would bear the burden of proving that a contracting course upon which they wished to embark, although presumptively disapproved by the newly amended Article $2 \mathrm{~B}$ of the U.C.C., nonetheless in fact disserved no greater purpose of copyright and contract law. 
To sum up, whether Article 2B should choose "neutrality" over proscribing illegitimate contracting practices is not an either/or choice between locating a debate in a federal forum as opposed to a state forum. The real questions are: (1) How will the preemption analysis unfold in state courts and under what presumptive standards (not whether it will take place)? (2) Who will bear the costs of attempting to diminish users' rights to increase protections for copyright owners (not whether such costs exist)? and (3) Who should be forced to make a federal case out of it before Congress, those who propose to tilt the delicate balance, or those who would seek to maintain it?

In deciding each of these questions, we come down firmly in favor of copyright, and suggest that the attempts to rework, alter, or eviscerate aspects of copyright through the vehicle of state contract law are illegitimate. Accordingly, in our view, it is those who alter the delicate balance who should bear the cost of this enterprise, and should be forced to rework copyright law where it has traditionally been reworked-in Congress.

\section{CONCLUSION}

It is emphatically not necessary to view copyright law as a "law of users' rights" (as have some ${ }^{245}$ ) to adopt the logic that undergirds this Article-that copyright has solicitude for the rights of both authors and of users. Instead, it is necessary simply to view copyright law as the carefully constructed compromise between society's disparate goals, reflecting the delicate equilibrium invoked so often throughout the discussion above. As the Supreme Court has taught, "[t]he economic philosophy behind the clause empowering Congress to grant patents and copyrights is the conviction that encouragement of individual effort by personal gain is the best way to advance public welfare through the talents of authors and inventors in 'Science and useful Arts." 246

By contrast, ${ }^{247}$ some may view copyright not as embodying any balance at all, but instead solely as a device to maximize the financial interest of proprietors. To them, unilateral expansion of the copyright monopoly beyond its congressionally sanctioned orbit is to be celebrated. Obviously, those adherents will remain unconvinced by the viewpoint expressed herein. But we think that Supreme Court pronouncements over the years, combined with innumerable statutory

245. See L Ray Patterson \& Stanley W. Lindberg, The Nature of Copyright: A LAW OF USERS' RIGHTS (1991).

246. Mazer v. Stein, 347 U.S. 201, 219 (1954).

247. For a view condemning copyright as a law of user rights but simultaneously acknowledging that "copyright loses much of its moral lustre" if confined purely to the goal of maximizing profits, see Jane C. Ginsburg, Authors and Users in Copyright, 45 J. CoPYRIGHT Soc'Y 1, 9 (1997). 
drafting choices, debunk the notion that copyright's vector points only in the direction of greater and greater magnitudes of protection. ${ }^{248}$

Nor do we think the following syllogism holds: "some copyright protection is good, quantity increases quality, therefore more copyright protection is better." 249 Instead, we believe that tipping the balance too precipitously in one direction can be as baleful as tipping it in the other. As passionate devotees of copyright, we can do no better than to close with Lord Mansfield's admonition of two centuries $\mathrm{ago}^{250}$ that the task for lawmakers ${ }^{251}$ is to pay careful heed to each of the two socially useful, but antithetical, interests inediated by copyright

We must take care to guard against two extremes equally prejudicial; the one that men of ability, who have employed their time for the service of the community may not be deprived of their just merits and reward for their ingenuity and labor; the other that the world may not be deprived of improveinents nor the progress of the arts be retarded." 252

"Expand through contract" is a slogan that offends a constitutionally defensible copyright regime. But when copyright's delicate equilibrium is respected, authors, publishers, users, and society at large are all winners.

248. Beyond the quotation from Mazer set forth immediately above, see the discussion above of Feist, Sony, Bonito Boats, and Campbell. See supra Part III.

249. In our Maimonidean attempt to achieve the golden mean, we are equally fervent in rejecting the converse syllogism that concludes that less copyright protection is better. For precisely that reason we reject the Charcutier Bill posited above, which would illegitimately increase user rights.

250. Lord Mansfield "is generally considered the single most influential Enghish jurist of the eighteenth century." MARK ROSE, AUTHORS AND OWNERS 68 (1993). His pedigree for current purposes is even more unassailable: as William Murray, before his elevation to the bench, he served as a practitioner in "most of the important Chancery cases concerning literary property, imcluding [Alexander] Pope v. Curll." Id.

251. His words are wise, we submit, for those who make laws in both the legislative and judicial branches, at both the state and federal level.

252. Sayre v. Moore (1785), quoted in Cary v. Longman, 102 Eng. Rep. 138, 139 n.(b) (K.B. 1801). 
